Topçu, F. K. (2021). Türkçe eğitimi alanında yapılmış dijital öğrenme tezlerinin incelenmesi. Ana Dili Eğitimi Dergisi, 9(4), 1338-1359.

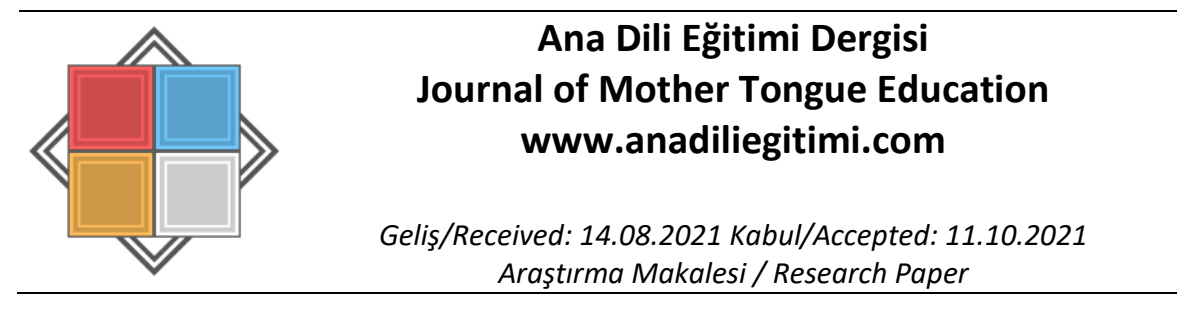

\title{
Türkçe Eğitimi Alanında Yapılmış Dijital Öğrenme Tezlerinin İncelenmesi
}

\author{
Furkan Kadir TOPÇU*
}

\begin{abstract}
Öz
Birçok alanda olduğu gibi Türkçe eğitiminde de dijital öğrenme konulu çalışmalar yapılmaktadır. Bu çalışmada Türkçe eğitimi alanında yapıımış dijital öğrenme konulu tezlerin farklı açılardan incelenmesi amaçlanmıştır. Bu şekilde alanın bir profili çizilerek alanda çalışacak araştırmacılara yol gösterilmiş olacaktır. Çalışma, YÖK Ulusal Tez Merkezi aracılığıyla araştırmanın amacı doğrultusunda yapılan tarama neticesinde elde edilen 41 tez ile sınırlandırılmıştır. Türkçe eğitimi alanında yapılmıs dijital öğrenme konulu tezlerin incelendiği bu çalışma nitel araştırma yöntemlerinden durum çalışması ile desenlenmiştir. Verilerin toplanmasında "Tez İnceleme Formu" kullanılmıştır. Toplanan ham verilerin araştırmanın amacı doğrultusunda belirlenmesi için "Tez Sınıflama Formu" oluşturulmuştur. Verilerin çözümlenmesinde betimsel analizden faydalanılmıştır. Sonuç olarak dijital öğrenme tezlerinde daha çok öğrencilerin pasif olduğu, uygulamalarda araştırmacı tarafından hazırlanan materyallerin kullanıldığı tespit edilmiştir. Buradan hareketle öğrencilerin aktif olduğu, dijital kanalları doğrudan kullanabildiği çalışmaların yapılması gerektiği söylenebilir. Öğrencilerin tutum, görüş, akademik başarılarının yanı sıra dijital yeterliklerinin de geliştirilmesine yönelik çalışmalar yapılmalıdır.
\end{abstract}

Anahtar Kelimeler: Dijital öğrenme, lisansüstü tezler, Türkçe eğitimi

\begin{abstract}
An Investigation of Digital Learning Theses in the Field of Turkish Education Abstract

Studies on digital learning are carried out in Turkish education as is the case in various other fields. This study aims to investigate digital learning in Turkish education through surveying the theses completed in the field. The goal is to create a profile of the field to guide researchers who will work in the field. The study is designed as a case study and is thus qualitative by design. In line with the goals of the study, the Higher Education Council National Thesis Center was surveyed and 41 theses on digital learning in Turkish education were found. A Thesis Review Form was used to collect data. A Thesis Classification Form was created to classify the collected data. Descriptive analysis was used for data analysis which revealed that students were mostly passive and that materials prepared by researchers were used. Based on the findings, it may be stated that studies that use digital channels directly and involve active student participation should be conducted to improve students' attitudes, opinions, and academic achievements as well as their digital competencies.
\end{abstract}

Keywords: Digital learning, graduate theses, Turkish education

\section{Giriş}

21. yüzyılda hayatın birçok noktasında meydana gelen değişmelerin temeli teknolojik değişmelerdir. Bu değişmelerle hayatımıza giren 'dijital' kavramı gündelik hayatımızın birçok yerinde karşımıza çıkmaktadır. Hayatımızın birçok noktasında farklı şekillerde karşımıza çıkan bu kavram beraberinde bazı sorumlulukları da getirmektedir. Bu sorumlulukların başında dijital yeterlikler gelmektedir. Türkçe eğitiminde de dijital yeterlikler önem arz etmektedir.

*Arş. Gör., Bartın Üniversitesi, Eğitim Fakültesi, Türkçe ve Sosyal Bilimler Eğitimi Bölümü, Bartın, ftopcu@bartin.edu.tr, ORCID: orcid.org/0000-0001-7198-5589 
'Dijital' kavramının geldiği 'digit' kelimesi '1 ile 10 arası sayıların her biri, rakam' (Nişanyan, Webster) şeklinde tanımlanmaktadır. 'Dijital' ise 'Elde edilen, ölçülen bilgileri sayılar hâlinde depolama ve ekranda ondalık sayı olarak gösterme (işlemi).' (Kubbealtı) şeklinde tanımlanmaktadır. Buradan hareketle dijital kavramının sayılarla gösterme işlemi olduğu söylenebilir. Bununla birlikte alanda, 'dijital' ve 'elektronik' kavramları birbirlerinin yerine kullanılmakla birlikte yalnızca 'dijital kütüphane' ve 'elektronik kütüphane' arasında (Özel 2016: 278) kütüphaneyi kullanma açısından bir fark ifade edilmiştir.

Dijital ortamlar, teknolojinin gelişmesi ile birlikte hayatımızda önemli bir yer edinmiştir. Bireylerin günlük yaşamlarında olduğu gibi okuma ve yazma becerilerinin yanı sıra dinleme ve konuşma becerilerinin kullanımlarında da değişim gözlenmektedir (Duran ve Ertan Özen 2018: 32).

Dijital öğrenme, tanım gereği e-öğrenme kavramının bir parçasıdır. Dijital öğrenme, çekici ve etkileşimli bir şekilde paketlenmiş hem yazııım hem de donanım kullanımı yoluyla öğrencilere dijital olarak öğrenmeleri için uygulanan öğrenme teknolojisinde yeni bir dönüm noktasıdır (Faridah vd. 2020).

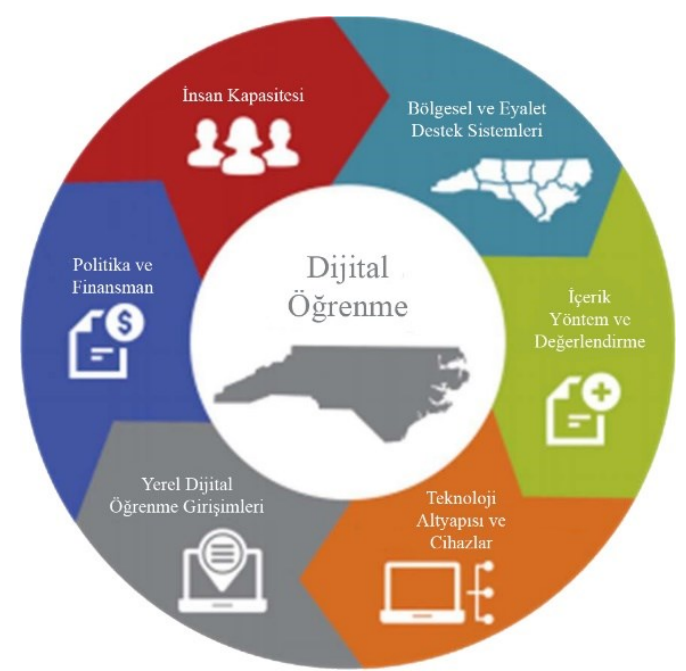

Şekil 1. Dijital Öğrenmenin Geliştirilmesi için Bir Çerçeve (Faridah vd. 2020)

Dijital teknolojilerle okuma ve yazma becerilerinin ilişkisi ele alındığında iki yönlü bir ilişkinin olduğu görülmektedir. Bunların ilki, bireylerin dijital ortamlarda karşılaştıkları yönergeleri, birtakım komutları, işaretleri ve görselleri doğru bir şekilde anlamlandırıp dijital araç gereçleri etkili bir şekilde kullanabilmelerini ifade etmektedir. Diğeri ise bireylerin oluşturdukları yazılı ve görsel materyalleri düzenli ve işlevsel bir şekilde paylaşabilmelerini içermektedir (Özbay ve Özdemir 2014: 32).

Web'in uzaktan eğitim etkinliklerinde kullanılmaya başlanması ile birlikte öğrenen bireylerin diğer bireylerle ya da öğretmenlerle tek veya çift yönlü daha etkin iletişim kurması ve etkileşime dayanan hizmetlerin sunulması (dinamik içerikli web sayfaları, e-posta, dosya transferi, tartışma listeleri, haber grupları, sohbet vb.) olanaklı hâle gelmiş, e-öğrenme kavramı ve öğrenme yönetim sistemleri yaygınlaşmaya başlamıştır (Özel 2016: 285).

Dijital ve çevrim içi olarak oluşturulan ve dağıtılan bütün konular, metin, resim, animasyon veya video biçiminde yazılıma entegre edilebilmektedir. Bu materyaller sadece bir bilgisayarda sistematik bir şekilde depolanan bilgi koleksiyonu değildir. Dijital öğrenme aynı zamanda tüm geleneksel öğretme ve öğrenme faaliyetlerini dijital formda birleştirebilir. Dijital öğrenmede, öğrencilerin teorik e-kitapları, video eğitimleri, uygulama soruları, deneysel simülasyonlar, istişareler, hatta öğrenciler için motivasyon özellikleri gibi dersleri anlamasını kolaylaştırabilecek bazı öğretim materyalleri referans olarak eklenebilmektedir (Faridah vd. 2020).

Dijital okuryazarlık (Martínez-Bravo 2020: 13) iki bakış açısıyla tanımlanmıştır. ilki, teknolojinin kullanımı için beceri-yeterliliklere odaklanmışır; ikincisi, öğretme-öğrenme ve stratejileri üzerinedir. Bu ikili bakış açısı, "dijital okuryazarlığı" yalnızca bir dizi yetkinliğin toplamı olarak değil, 
aynı zamanda tasarım ve uygulamadan çeşitli özelliklerin dâhil olduğu yetkinliklerin değerlendirilmesine kadar giden bir süreç olarak tanımlamıştır.

Luong ve Arnold (2020: 787), internet teknolojisini kullanan eğitimin yeni bir eğitim olmadığııı, akademisyen ve araştırmacıların yıllardır araştırmalar yayınladığını ifade etmiştir. Ayrıca, uzaktan öğretimin salgından önce daha çok yükseköğretimde kullanıldığını, sınıfta teknoloji kullanımının verimliliği artırmanın bir yolu olduğunu ifade etmiştir.

Bilgisayar ve internet teknolojilerinin yaygınlaşmasıyla birlikte elektronik ortamda öğrenme fikri dünya çapında büyük ilgi görmüştür. 1960 'larda bilgisayarların ortaya çıkmasından günümüze kadar e-öğrenme çabalarını üç büyük dönüşüm temelinde incelemek mümkündür. Öğretimi desteklemek amacıyla temel becerilerin öğretilmesinde alıştırma ve pratiğe dayanan eğitim yazılımlarıyla başlayan elektronik ortamda öğrenme yönelimi, özellikle 1991'de www'ya kavuşan internetin anında iletişim olanaklarıyla büyük bir ivme kazanmıştır. Böylece bilgisayar tabanlı eğitim yazılımları yerini sunucu tabanlı öğrenme yönetim sistemlerine (LMS) bırakmıştır. Dolayısıyla içerik oluşumu ve kontrolü de CD-ROM'dan web tabanlı yazılım dillerine yükselmiştir (Fırat 2009: 28).

Türk eğitim sisteminde son yıllarda beceri odaklı yapılandırmacı eğitim modelinin benimsenmesiyle öğretmen ve öğrenci rolleriyle öğrenme ve öğretme ortamları değişmiştir. Çoklu ve zengin öğrenme ortamlarının bir gereği olarak öğrenci ve öğretmenlerin artık eskisinden çok daha fazla bilişim teknolojisi kullanması gerekmektedir. Sınıf içinde ve dışında öğrencilere verilen öğrenme fırsatları, birçok öğrenme görevi ve projeler onların teknolojiyi amacına yönelik olarak kullanmasını gerektirmektedir (Karadüz ve Baytak 2010: 10).

Türkçe Dersi Öğretim Programı (MEB 2019: 5) 'yetkinlikler' bölümünde 'dijital yetkinlik' “iş, günlük hayat ve iletişim için bilgi iletişim teknolojilerinin güvenli ve eleştirel şekilde kullanılmasını kapsar. Söz konusu yetkinlik, bilgiye erişim ve bilginin değerlendirilmesi, saklanması, üretimi, sunulması ve alışverişi için bilgisayarların kullanılması ayrıca internet aracılığıyla ortak ağlara katılım sağlanması ve iletişim kurulması gibi temel beceriler yoluyla desteklenmektedir." şeklinde ifade edilmiştir. Yine programdaki "Kısa ve basit dijital metinlerdeki mesajı kavrar." kazanımı dijital yetkinliğin Türkçe derslerindeki yerini göstermektedir. Bununla birlikte 21. yy. becerileri içinde yer alan 'dijital okuryazarlık' kavramı birçok derste kullanılmaktadır. Dijital okuryazarlık (Trilling, Fadel 2009: xxvi), 21. yy. becerilerini meydana getiren üç gruptan biridir. Bu açıdan bakıldığında eğitimin temel bileşenlerinden birini meydana getirmektedir. Dijital okuryazarlık ise "bilgi okuryazarlığı, medya okuryazarlığı ile bilgi ve iletişim teknolojileri (BіT) okuryazarlığı"nı içermektedir. Bilgisayar ve teknolojinin hayatın her sahasına girmesiyle eğitimin de buna uyum sağlaması gerekmektedir. Küresel bir hareket, dijital öğrenen grubu için eğitim araçlarını yeniden ayarlamak ve öğrenmeyi 21. yüzyılın yeni hareket tarzlarıyla eş zamanlı hâle getirmek için çalışmaktadır (Trilling, Fadel 2009: xxviii). 21. yy. da hayatın yeni öğrenme yollarını dört güçlü kuvvet birleşerek meydana getirmektedir. Bunlar; bilgi çalışmaları, düşünme araçları, dijital hayat tarzları ve öğrenme araştırmalarıdır (Trilling, Fadel 2009: 21). Buradan hareketle yeni eğitim anlayışlarında dijitallikten uzak bir yaklaşım sergilenemeyeceği söylenebilir.

Türkçe eğitiminde birçok farklı teknoloji tabanlı uygulama kullanılmaktadır. Altunbay ve Bıçak (2018: 140), Türkçe eğitiminde kullanılabilirliği tespit edilen teknoloji tabanlı uygulamaları şu şekilde ifade etmiştir:

- Artırımış gerçeklik

- Eğitsel yazilımlar

- Etkileşimli tahta

- Web tabanlı öğretim

- Mobil öğretim

- Bilgisayar destekli öğretim

- Bilgisayar tabanlı öğretim

- Uzaktan öğretim

Eğilim araştırmaları, farklı bilim dallarının içerisinde belirli konularda veya alanının tamamını ilgilendirecek şekilde alandaki çalışmaların profillerini, perspektiflerini ortaya koyma amaçlı 
yapılmaktadır. Bu çalışmalar alanla ilgili genel bir bakış açısı sunmakla birlikte araştırmacılara fikir vererek bir başlangıç noktası oluşturmaktadır. Bu sebeple ilk olarak Türkçe eğitimi alanında yapılmış eğilim araştırmaları incelenmelidir. Farklı açılardan Türkçe eğitimiyle ilgili akademik çalışmalara yaklaşan ve değerlendirmeler yapan eğilim araştırmaları bulunmaktadır (Aktaş ve Uzuner Yurt 2015; Arı 2020; Aytaş ve Özcan 2018; Boyacı ve Demirkol 2018; Bozkurt ve Uzun 2015; Ceran 2018; Coşkun 2012; Doğan ve Özçakmak 2014; Dönmez ve Gündoğdu 2016; Karagöz ve Şeref 2019; Kemiksiz 2017; Öz 2020; Özçakmak 2017; Özdemir 2018; Tok ve Potur 2015; Varışoğlu vd. 2013; Yanbıyık ve Yılmaz 2016). Bu çalışmalar, Türkçe eğitiminde yapılmış eğilim araştırmalarıyken Türkçe eğitiminde teknoloji tabanlı çalışmalar da yapılmıştır (Aşcı 2019; Baki ve Feyzioğlu 2017; Bal 2018; Bal 2019; Bal ve Uslu 2018; Benzer 2018; Dayan ve Girmen 2018; Demirer ve Baki 2018; Eroğlu 2020; Ertem 2016; Işıksalan 2020; Karakuş Tayşi 2019; Kurudayıoğlu ve Bal 2014; Kurudayıoğlu ve Soysal 2020; Mete 2021; Özbay ve Özdemir 2014; Özdemir 2017; Özerbaş ve Öztürk 2017; Özkaya 2020; Yılmaz vd. 2017). Dijital çalışmaları inceleyen az sayıda çalışma mevcuttur. Türkçe eğitimindeki dijital çalışmaları inceleyen az sayıdaki çalışmalar; dijital öyküleme ile ilgili çalışmaları inceleyen Turgut ve Kışla (2015), Talan (2019) ve Özkaya (2020); mobil öğrenme üzerine çalışan Korucu ve Biçer (2018); e-öğrenme ortamlarıyla ilgili yapılan tezleri ana bilim dalı ayrımı olmadan inceleyen Delen (2021); çevrim içi okuma üzerine yapılan çalışmaları inceleyen Çifci ve Ünlü (2020); Türkçe eğitiminde teknoloji kullanımına yönelik yapılan tezleri inceleyen Şahin vd. (2020); Türkçe eğitiminde web 2.0 uygulamalarının kullanımına dair örnekler sunan Benzer (2017); Türkçe eğitiminde dijital yetkinlik kavramını inceleyen Geçgel vd. (2020); video oyunları üzerinden WoS tabanındaki makaleleri inceleyen (Altınpulluk; 2021) çalışmalar olarak sayılabilir.

Türkçe eğitiminde dijital çalışmaların artması, bu tür çalışmaların incelenmesiyle sağlanabilir. Dijital öğrenme alanındaki çalışmaların eğilimlerini görmek, araştırmacılara yol gösterecektir. Bu çalışmada dijital öğrenme tezlerinin genel eğilimi ortaya çıkarılmaya çalışılış̧tır. Bu açıdan çalışma "Türkçe eğitimi alanında yapılmış dijital öğrenme tezlerinin eğilimi nasıldır?" sorusu etrafında şekillenmiştir.

Teknoloji ve internet günlük hayatta giderek daha önemli roller oynamaya başladıkça birçok kişinin ilgisi, dijital bağlamlarda okuryazarlığın değişen doğasını anlamaya yönelmiştir (Noguerón-Liu ve Lammers 2020: 408). Dijitalliğin anlamlandırılması, kullanılması ve bu alanda yapılan çalışmalar önemli hâle gelmiştir. Bu kapsamda, Türkçe eğitimi alanında yapılmış dijital öğrenme konulu tezlerin farklı açılardan incelenerek genel yapısının ortaya konması amaçlanmıştır.

Çalışmada şu araştırma sorularına cevap aranmıştır:

1. Türkçe eğitimi alanında yapılmış dijital öğrenme tezlerinin yıllara göre dağılımı nasıldır?

2. Türkçe eğitimi alanında yapılmış dijital öğrenme tezlerinin konuları açısından dağılımı nasıldır?

3. Türkçe eğitimi alanında yapılmış dijital öğrenme tezlerinin problem, alt problem ve amaç açısından dağılımı nasıldır?

4. Türkçe eğitimi alanında yapıımış dijital öğrenme tezlerinin sonuçları açısından dağılımı nasıldır?

5. Türkçe eğitimi alanında yapılmış dijital öğrenme tezlerinin çalışma grupları açısından dağııımı nasıldır?

6. Türkçe eğitimi alanında yapılmış dijital öğrenme tezlerinin çalışma gruplarının büyüklüğü açısından dağılımı nasıldır?

7. Türkçe eğitimi alanında yapılmış dijital öğrenme tezlerinin yaklaşım ve desenleri açısından dağııımı nasıldır?

8. Türkçe eğitimi alanında yapılmış dijital öğrenme tezlerinin veri toplama araçları açısından dağııımı nasıldır?

\section{Araştırmanın Modeli}

\section{Yöntem}

Türkçe eğitimi alanında yapılmış dijital öğrenme konulu tezlerin incelendiği bu çalışma nitel araştırma yöntemlerinden durum çalışması ile desenlenmiştir. Yıldırım ve Şimşek'e göre (2018: 289) 
durum çalışması araştırmacının kontrol edemediği bir olgu ya da olayı derinliğine incelemesine imkân veren bir araştırma yöntemidir. Bu çalışmada incelenen tezlerin özellikleri ve eğilimleri olduğu gibi doğrudan incelendiği için durum çalışması kullanılmıştır.

\section{Veri Toplama Araçları}

$\mathrm{Bu}$ çalışmada verilerin toplanmasında doküman incelemesi kullanılmıştır. Doküman incelemesi, araştırılması hedeflenen olgu veya olgular hakkında bilgi içeren yazılı materyallerin analizidir (Yıldııım ve Şimşek 2018: 189).

Bu çalışmada veri toplama sürecinde "Tez İnceleme Formu" kullanılmıştır. Form, bu çalışma için araştırmacı tarafından alanda yazılanlar ve çalışmanın amaç ve araştırma soruları doğrultusunda hazırlanmıştır. İlk olarak, çalışmanın amacı ve araştırma soruları doğrultusunda formda yer alacak birimler belirlenmiştir. Bu belirleme neticesinde elde edilen form, iki alan uzmanına (Türkçe Eğitiminde Dr. Öğr. Üyesi ve Arş. Gör.) gönderilerek formla ilgili görüşleri alınmış ve forma son hâli verilmiştir. Form içerisinde "tez adı, türü, yıl, konu, araştırmanın problemi, araştırmanın alt problemleri, araştırmanın amacı, çalışma grubu, kullanılan yöntem-desen, verilerin toplanması, sonuç" başlıkları kullanılmıştır. Bu başlıkların belirlenmesinde araştırmanın amacı ve soruları esas alınmıştır. Bu doğrultuda araştırmacı tarafından incelenmek istenen özellikler için başlıklar belirlenmiştir.

Bir başka veri toplama aracı olan ve toplanan ham verilerin araştırmanın amacı doğrultusunda belirlenmesi için "Tez Sınıflama Formu" oluşturulmuştur. Bu form, ilk tarama sonrasında elde edilen tezlerin amaca uygunluğunun tespiti için kullanılmıştır. Ilk tarama, geniş bir alandan ve sınırlandırma olmaksızın yapıldığından elde edilen tezlerin amaca uygun olanlarının tespiti gerekmiştir. Oluşturulan bu form ile çalışmanın amacına uygun olan tezler belirlenmiştir.

\section{Verilerin Toplanması}

Çalışmada kullanılacak verileri toplamak amacıyla "YÖK Ulusal Tez Merkezi" aracılığıyla Türkçe eğitimi alanında yapılmış dijital öğrenme tezleri taranmıştır. Taramalar, 19.03.202108.04.2021 tarihleri arasında yapılmıştır. Çalışmaya dâhil edilen tezler Ek-1'de sunulmuştur. Bu tarihlerden sonra eklenmiş olabilecek tezler, bu çalışmanın dışındadır. Tarama yapılırken dijital alanda yapılan tezlerin birçok farklı kavram kullanılarak isimlendirildiği fark edildiğinden anahtar kavram kullanmak yerine "YÖK Ulusal Tez Merkezi”nde 'Detaylı Tarama' bölümünde iki kademeli bir tarama yapılmıştır. Taramanın birinci kademesinde "İzin durumu, izinli; durumu, onaylandı; dil, Türkçe; grubu, sosyal ve ana bilim dalı sırasıyla, Sosyal Bilgiler ve Türkçe Eğitimi, Türkçe, Türkçe Eğitimi, Türkçe Öğretimi, Türkçe Öğretmenliği, Türkçe ve Sosyal Bilgiler, Türkçe ve Sosyal Bilimler, Türkçe ve Sosyal Bilimler Eğitimi, Türkçenin Eğitimi ve Öğretimi" seçilmiştir. Taramanın ikinci kademesinde "izin durumu, izinli; durumu, onaylandı; dil, Türkçe; grubu, sosyal ve bilim dalı, Türkçe Eğitimi, Türkçe Öğretmenliği, Türkçenin Eğitimi ve Öğretimi” seçilerek tarama tamamlanmıştır. İkinci kademede çoğunlukla birinci kademede ulaşılan tezlere ulaşıımıştır fakat buradaki amaç, ana bilim dalı Türkçe Eğitimi haricinde bir ana bilim dalı olup Türkçe Eğitimi bilim dalında yapılan tezlerdir. Nitekim bu türden tezlerle de karşılaşılmıştır. Taramalarda tezler isimleriyle incelenmiş, çalışmanın güvenirliğini zedelememesi açısından dijitalliği, teknolojiyi çağrıştıran bütün tezler verilere dâhil edilmiştir. Bu noktada "Yabancılara Türkçe Öğretimi" konusundaki tezler kapsam dışında bırakılmıştır. Bu taramalar neticesinde 115 teze ulaşılmıştır. Bu tezler "Tez Sınıflama Formu" meydana getirilerek iki alan uzmanına gönderilmiş, çalışmanın amacı olan 'dijital' kavramına girip girmeyeceğine göre sınıflandırmaları istenmiştir. Araştırmacının da aynı sınıflandırmayı yapmasıyla üç ismin sınıflaması neticesinde 115 tezin $71^{\prime}$ inde ortaklık sağlanmıştır. Illk sınıflamada ortaklık sağlanamamış, 44 tez yeniden incelenmiş, gerektiğinde içerikleri değerlendirilmiştir. Bu sınıflandırmalar neticesinde $10^{\prime} u$ doktora, $31^{\prime} i$ yüksek lisans olmak üzere toplam 41 tez bu çalışmanın verilerini meydana getirmiştir. Gerek tarama sırasında gerekse elde edilen tezlerin son sınıflaması esnasında bu kapsamın dışına çıkılmamıştır. Son sınıflamada çıkarılan tezler, çalışmadaki 'dijital' kavramına uygun olmadığı için kapsam dışında bırakılmıştır. 


\section{Verilerin Analizi}

Bu çalışmada verilerin çözümlenmesinde betimsel analizden faydalanılmıştır. Betimsel analizde elde edilen veriler, daha önceden belirlenen temalara göre özetlenir ve yorumlanır. Veriler, önce sistematik ve açık bir biçimde betimlenir. Daha sonra yapılan bu betimlemeler açıklanır ve yorumlanır, neden-sonuç ilişkileri irdelenir ve birtakım sonuçlara ulaşılır (Yıldırım ve Şimşek 2018: 239-240). Çalışmaya dâhil edilen tezler "Tez İnceleme Formu"na işlenmiştir. Formdaki "Tez adı, türü, yılı, konusu, araştırma problemi, araştırmanın alt problemleri, araştırmanın amacı, çalışma grubu, kullanılan yöntem/desen, verilerin toplanması, sonuç" sütunları her bir tez için doldurulmuştur. Bütün tezlerin forma işlenmesinin ardından her bir birim için veriler bir araya getirilerek temalar oluşturulmuş, sonrasında tablolara aktarılmıştır.

\section{Geçerlik ve Güvenirlik}

Tezlerin çalışmaya dâhil edilmesi sürecinde YÖK Ulusal Tez Merkezinde Türkçe Eğitimi alanında bulunan bütün tezler, isimleri esas alınarak taranmıştır. Bu taramada 'teknoloji' ve 'dijital' kavramlarını çağrıştıran bütün tezler toplanmıştır. Sonrasında araştırmacıyla birlikte iki uzmana (Dr. Öğr. Üyesi ve Arş. Gör.) "Tez Sınıflama Formu" ve toplanan tezler gönderilmiştir. Araştırmacı ve iki uzman tarafından yapılan sınıflamaya göre çalışmaya dâhil edilecek tezler belirlenmiştir. Bu açıdan, çalışmaya dâhil edilen tezler araştırmanın amacına uygundur. Çalışmaya dâhil edilen tezlerin incelenmesi esnasında "Tez İnceleme Formu"na işlenen veriler, formdaki bölümlere uygun olarak tezlerden aynen aktarımıştır. Bu işlemin ardından her bir sütundaki veriler birleştirilerek değerlendirilmiştir. Bu işlem araştırmacı tarafından veriler tezden aynen alınarak yapılmıştır. Kullanılan verilerin hiçbirine araştırmacı tarafından müdahale edilmemiştir. Verilerin toplanması ve analizi sürecinde bulgular, ham verilerle desteklenerek ifade edilmiştir. Ayrıca tablolarla ifade edilen bütün veriler, alındıkları tezlerle desteklenmiştir.

\section{Araştırma ve Yayın Etiği}

Bu çalışmada "Yükseköğretim Kurumları Bilimsel Araştırma ve Yayın Etiği Yönergesi" kapsamında uyulması belirtilen tüm kurallara uyulmuştur. Yönergenin ikinci bölümü olan "Bilimsel Araştırma ve Yayın Etiğine Aykırı Eylemler" başlığı altında belirtilen eylemlerden hiçbiri gerçekleştirilmemiştir.

\section{Bulgular}

Bu bölümde çalışmanın amaç ve araştırma soruları doğrultusunda bulgular verilmiştir. Tablolarda bulunan Y3, D6 gibi ifadeler Ek-1'de belirtilen tezlerin numaralarıdır.

\section{Birinci araştırma sorusuna ilişkin bulgular}

Tablo 1.

Tezlerin Tür ve Yıllara Göre Dağılımı

\begin{tabular}{cccccc}
\hline & Sıklık & $\begin{array}{c}\text { Yüksek lisans } \\
\text { Bulunan tezler }\end{array}$ & Sıklık & $\begin{array}{c}\text { Doktora } \\
\text { Bulunan tezler }\end{array}$ & Toplam \\
2009 & 1 & Y30 & - & - & 1 \\
2010 & - & - & - & - & - \\
2011 & 1 & Y14 & 1 & D5 & 2 \\
2012 & - & - & - & - & - \\
2013 & 2 & Y6, Y27 & 3 & D2, D8, D10 & 5 \\
2014 & - & - & 1 & D9 & 1 \\
2015 & 1 & Y15 & 1 & D4 & 2 \\
2016 & 3 & Y7, Y17, Y25 & - & - & 3 \\
2017 & 2 & Y16, Y31 & 1 & D1 & 3 \\
2018 & 5 & $Y 2, Y 5, Y 9, Y 11, Y 19$ & - & - & 5 \\
2019 & 10 & Y1, Y3, Y10, Y18, Y20, Y22, Y23, & 1 & D7 & 11 \\
\hline
\end{tabular}


Y24, Y28, Y29

\begin{tabular}{cccccc}
2020 & 6 & $Y 4, Y 8, Y 12, Y 13, Y 21, Y 26$ & 2 & $D 3, D 6$ & 8 \\
\hline Toplam & $31(\% 76)$ & & $10(\% 24)$ & & 41 \\
\hline
\end{tabular}

Birinci araştırma sorusuna ilişkin bulgular incelendiğinde doktora tezlerinin daha dengeli bir dağılım gösterdiği, buna karşın yüksek lisans tezlerinde 2017 yılından sonra bir artış olduğu söylenebilir. Bu artışta Türkçe Öğretim Programındaki değişikliklerin etkisi olabilir. Toplam sayılara bakıldığında en fazla çalışmanın (Y1, Y3, Y10, Y18, Y20, Y22, Y23, Y24, Y28, Y29) 2019 yılında yapıldığı sonucuna ulaşılabilir. 2020 yılında başlamış olan salgının burada etkili olduğu söylenebilir. Bununla birlikte ilerleyen yıllarda dijital öğrenme ile ilgili tezlerde artış görülebilir. Tezlerin türleri açısından değerlendirilmesinde ise doktora tezlerinin toplam tezlerin 1/4'ünü oluşturduğu görülmektedir.

\section{İkinci araştırma sorusuna ilişkin bulgular}

Tablo 2

Tezlerin Ana Konu Dağılımı

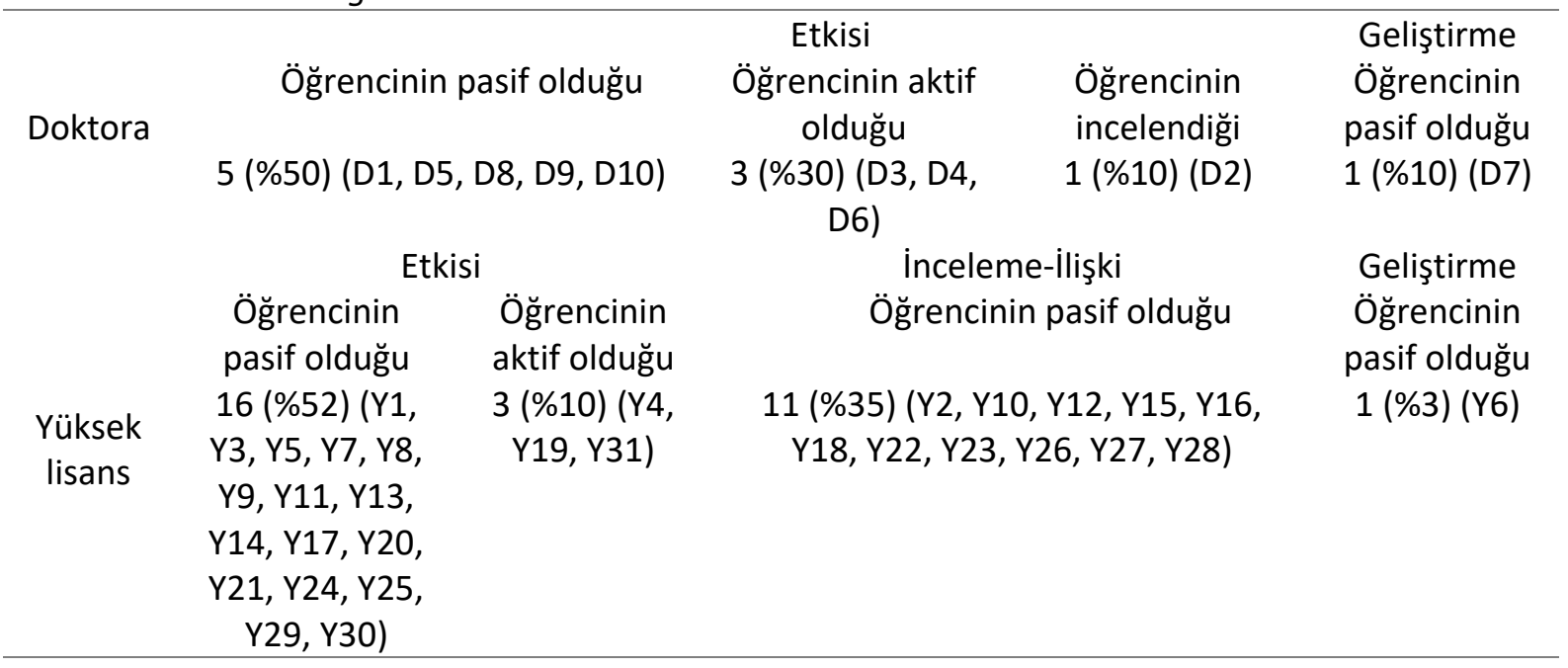

Çalışmada incelenen tezler, konularının dağılımı açısından incelendiğinde ilk karşılaşılan husus çalışmalara yaklaşma şekilleridir. Bu kapsamda tezlerin bir yöntemin-uygulamanın öğrencilerin çeşitli becerilerine etkisini incelediği görülmektedir. Doktora tezlerinin tamamına yakını bu türden tezlerden meydana gelmekteyken yüksek lisans tezlerinin \%62'si etki inceleyen tezlerdendir. Bunun altındaki sınıflandırma dikkate alındığında ise çalışmalarda nasıl bir yol izlendiği, yöntemin nasıl gerçekleştiği görülmektedir. Bu bölümde özellikle öğrencilerin uygulama süresince aktif veya pasif olduğu çalışmalar göze çarpmaktadır. Öğrencilerin aktif olduğu çalışmalardan kasıt uygulanan yazılım, program, uygulama vb.nin doğrudan öğrenciye kullandırıldığı çalışmalardır. Buna karşın öğrencilerin pasif olduğu çalışmalarda; kullanılan yazııı, program, uygulama vb.nin araştırmacı tarafından Türkçe eğitimine uygun olarak hazırlandığı ve öğrencilere sunulduğu görülmektedir. Bütün çalışmalara bakıldığında öğrencilerin pasif olduğu çalışmaların bütün çalışmalarda büyük oranda yer aldığı görülmektedir. Bununla birlikte doktora ve yüksek lisans tezlerinde öğrencilerin pasif olduğu çalışmalara bakıldığında doktora tezlerinde bu oranın daha düşük olduğu görülmektedir.

Tablo 3.

Tezlerin Konu Dağılımı

\begin{tabular}{lcc}
\hline Doktora & Sıklık & Bulunan tezler \\
dijital hikaye & 4 & D1, D3, D4, D6 \\
web tabanlı uzaktan öğretim & 3 & D2, D9, D10 \\
etkileşimli bilgisayar uygulaması & 2 & D5, D8
\end{tabular}




\begin{tabular}{|c|c|c|}
\hline elektronik sözlük & 1 & D7 \\
\hline \multicolumn{3}{|l|}{ Yüksek lisans } \\
\hline web 2.0 uygulamaları & 6 & $Y 8, Y 20, Y 23, Y 29, Y 31, Y 19$ \\
\hline bilgisayar destekli öğretim & 6 & $\mathrm{Y} 3, \mathrm{Y} 11, \mathrm{Y} 15, \mathrm{Y} 17 \mathrm{Y} 22, \mathrm{Y} 27$ \\
\hline bilgisayar destekli eğitsel oyunlar & 4 & $Y 1, Y 5, Y 13, Y 24$ \\
\hline basılı ve dijital ortamda okuduğunu anlama becerisi & 4 & $\mathrm{Y} 2, \mathrm{Y} 12, \mathrm{Y} 14, \mathrm{Y} 21$ \\
\hline $\begin{array}{l}\text { ortaokul öğrencilerinin wattpad uygulaması } \\
\text { kullanımı }\end{array}$ & 2 & $\mathrm{Y} 16, \mathrm{Y} 28$ \\
\hline z-kitap, elektronik ders kitabı & 2 & Y7, Y25 \\
\hline dijital hikaye & 2 & Y9, Y10 \\
\hline internete yönelik epistemolojik inanç & 1 & Y26 \\
\hline webquest (web macerası) yöntemi & 1 & Y30 \\
\hline Çevrim içi iş birlikli öğrenme yöntemi & 1 & Y4 \\
\hline sözlük geliştirme & 1 & Y6 \\
\hline e-yazma alışkanlıkları & 1 & Y18 \\
\hline
\end{tabular}

Konu açısından tezler en çok dijital hikâye ve bilgisayar destekli çalışmalara yönelmiştir. Doktora tezlerinde dijital hikâye ilk sıradayken yüksek lisans tezlerinde bu oran düşmektedir. Yüksek lisans tezlerindeyse web 2.0 uygulamaları ile bilgisayar destekli öğretim ön plana çıkmıştır.

\section{Üçüncü araştırma sorusuna ilişkin bulgular}

Tablo 4.

Tezlerin Problem, Alt Problemler ve Amaç Açısından Dağılımı

\begin{tabular}{|c|c|c|}
\hline & & Sıklık \\
\hline & akademik başarı ve tutum & 7 (\%54) (D1, D5, D7, D8, D9, D10) \\
\hline & yazma becerileri, yazma kaygıları, özyeterlik & $3(\% 23)(D 4, D 6, D 9)$ \\
\hline Roktora & vurgu ve tonlama & $1(\% 8)(\mathrm{D} 2)$ \\
\hline DOKLOTd & dijital okuryazarlıklar & 1 (\%8) (D6) \\
\hline & $\begin{array}{l}\text { geleneksel yöntemle farkları açısından } \\
\text { değerlendirmektir. }\end{array}$ & $1(\% 8)(\mathrm{D} 3)$ \\
\hline & tutum ve başarı & $\begin{array}{c}18(\% 38)(Y 1, Y 3, Y 4, Y 7 Y 8, Y 9, Y 11, Y 13, \\
Y 14, Y 15, Y 17, Y 19, Y 20, Y 24, Y 25, Y 27, \\
Y 29, Y 30)\end{array}$ \\
\hline & $\begin{array}{l}\text { yazma özyeterliği, becerisi, duyarlılı̆̆ı, } \\
\text { psikolojisi, kaygısı, farkındalığı }\end{array}$ & 7 (\%16) (Y4, Y10, Y15, Y16, Y18, Y19, Y31) \\
\hline & okuduğunu anlama & $4(\% 8)(Y 2, Y 7, Y 14, Y 21)$ \\
\hline & okuma özyeterliği & $2(\% 4)(Y 12, Y 16)$ \\
\hline & görüş & $2(\% 4)(Y 22, Y 26)$ \\
\hline & motivasyon & $2(\% 4)(Y 24, Y 29)$ \\
\hline Yüksek & kişisel ilerleme algısı & $1(\% 2)(\mathrm{Y} 10)$ \\
\hline lisans & genel ilerleme algısı & $1(\% 2)(Y 10)$ \\
\hline & öğrenici sözlüğü hazırlamak & $1(\% 2)(Y 6)$ \\
\hline & normal öğretimle farkı & $1(\% 2)(Y 3)$ \\
\hline & dilbilgisi & $1(\% 2)(Y 1)$ \\
\hline & hazırbulunuşluk & $1(\% 2)(Y 15$ \\
\hline & kalıcilık & $1(\% 2)(Y 17)$ \\
\hline & web 2.0 araçlarının kullanılma durumu & $1(\% 2)(Y 23)$ \\
\hline & özyeterlik inancı & $1(\% 2)(Y 25)$ \\
\hline & epistemolojik inanç & $1(\% 2)(Y 26)$ \\
\hline
\end{tabular}




\begin{tabular}{lc}
\hline e-yazma alışkanlıkları & $1(\% 2)(\mathrm{Y} 18)$ \\
metinde bulunması gereken özellikler & $1(\% 2)(\mathrm{Y} 28)$ \\
sözcük öğrenme açısından değerlendirmektir. & $1(\% 2)(\mathrm{Y} 5)$ \\
\hline
\end{tabular}

Çalışmaya konu olan tezler; problem, alt problem ve amaç açısından bütüncül bir yaklaşımla incelenmiştir. Bunun sebebi çalışmalarda bu üç başlığın birbiriyle yakın ve ilgili olarak ifade edilmesidir. Bu şekilde çalışmada aynı verilerin tekrarından uzak kalınmıştır. Her iki grupta da akademik başarı ve tutum ile yazma becerilerinin incelenmesinin hedeflendiği görülmektedir. Bu sonuç diğer sonuçlarla paralellik göstermektedir.

\section{Dördüncü araştırma sorusuna ilişkin bulgular}

Tablo 5.

Tezlerin Sonuçları Açısından Dağılımı

Bilgisayar destekli öğretim, mevcut öğretime göre;

derse karşı tutum

dil bilgisi, akademik başarı

kalıcılık üzerinde

vurgu, ton ve duyguyu algılama ve yansıtma becerilerini geliştirmede yaratıcı düşünme becerisini geliştirmede

öğrenciler üzerinde pozitif bir etki oluşturmada

yazma kaygısı

dijital okuryazarlık

sözcük öğretimi üzerinde

zaman ve mekândan bağımsız eğitim verebilmede

üç boyutlu materyal hazırlama konusunda etkili olduğu ifade

edilmiştir.

başarı

tutum

yazma becerisi, yazma kaygısı, yazma duyarııı̆ı

dersleri eğlenceli hâle getirdiği

Yüksek

lisans kalıclık

\section{motivasyon}

ekran okumanın kâğıttan okuduğunu anlama başarısının seviyesine ulaştığı

noktalama işaretleri kazanımlarını olumlu yönde etkilediği

derlem tabanlı bir sözlüğün oluşturulduğu

z-kitap kullanımının öğrencilerin okuduğunu anlamaları

Wattpad'in okuma ve yazma maksadıyla kullanıldığı, öğrencilerin macera ve kurgu türünde kitapları okuduğu, Wattpad'den kitap okuyan ortaokul öğrencilerinin anne-baba eğitim düzeyi dijital
Sıklık

5 (\%28) (D1, D5,

$\mathrm{D} 6, \mathrm{D} 8, \mathrm{D} 10)$

4 (\%22) (D1, D3,

$\mathrm{D} 5, \mathrm{D} 10)$

$1(\% 5,5)$ (D1)

$1(\% 5,5)$ (D2)

$1(\% 5,5)$ (D3)

$1(\% 5,5)$ (D4)

$1(\% 5,5)(D 6)$

$1(\% 5,5)(D 6)$

$1(\% 5,5)$ (D7)

$1(\% 5,5)$ (D9)

$1(\% 5,5)$ (D10)

8 (\%21) (Y1, Y8,

$\mathrm{Y} 11, \mathrm{Y} 13, \mathrm{Y} 17$,

$\mathrm{Y} 20, \mathrm{Y} 24, \mathrm{Y} 30)$

8 (\%21) (Y1, Y8,

$Y 11, Y 13, Y 14$,

Y19, Y20, Y27, Y30)

4 (\%10) (Y4, Y10,

Y15, Y19)

3 (\%7) (Y9, Y20,

Y22)

2 (\%5) (Y17,

$\mathrm{Y} 21)$

2 (\%5) (Y2, Y29)

1 (\%3) (Y2)

1 (\%3) (Y3)

1 (\%3) (Y6)

1 (\%3) (Y7)

1 (\%3) (Y16) 
ortamdan kitap okumayan ortaokul öğrencilerinin anne-baba eğitim düzeyinden anlamlı derece yüksek çıktı̆̆ı

öğretmen adaylarının özyeterlik düzeyleri üzerinde etkili olduğu

$1(\% 3)(\mathrm{Y} 12)$

e-yazma alışkanlığını olumlu yönde etkilediği

$1(\% 3)(\mathrm{Y} 18)$

teknoloji kullanımının en çok dinleme becerisini etkilediği

$1(\% 3)(\mathrm{Y} 22)$

Türkçe dersi ile web 2.0 araçlarının ilişkilendirilmesi gerekliliği

$1(\% 3)(\mathrm{Y} 31)$

Öğretmen adaylarının epistemeolojik inançlarının orta düzeyde

$1(\% 3)(\mathrm{Y} 26)$

olduğu

sözcük bilgisini artırdığı sonuçlarına ulaşılmıştır.

$1(\% 3)(\mathrm{Y} 5)$

Öte yandan;

elektronik uygulamasının EBA ile karşılaştırıldığında akademik

başarılarını ve tutumlarını anlamlı düzeyde etkilemediği

$2(\% 25)(Y 20$,

yazma özyeterliği açısından fark bulunmadığı

$1(\% 12,5)(\mathrm{Y} 10)$

Wattpad'de geçirdikleri vakit ile okur özyeterlikleri ve yazma

$1(\% 12,5)(\mathrm{Y} 16)$

özyeterlikleri arasında bir ilişki bulunmadığı

Web 2.0 uygulamalarında içerik bulmada zorlanma, erişim sorunları,

$1(\% 12,5)(\mathrm{Y} 23)$

sosyal ortama kendilerini fazla kaptırmaları gibi durumların yaşandığı

Wattpad'taki kitapların olumsuz davranışların bulunduğu, edebi

$1(\% 12,5)(Y 28)$

dilden uzak olduğu

başarı puanında anlamlı bir artışın olmadığı

$1(\% 12,5)(Y 29)$

yazma kaygısına etki etmediği gibi sonuçlara ulaşıımıştır.

$1(\% 12,5)(Y 4)$

Ele alınan tezler, sonuçları açısından değerlendirildiğinde problemleri doğrultusunda bulgular elde edilmektedir. Her iki grupta da akademik başarı ve tutum ilk sırada yer almaktadır. Bunun yanı sıra yüksek lisans tezlerinde olumsuz sonuçlar elde edildiği ifade edilmiştir.

\section{Beşinci araştırma sorusuna ilişkin bulgular}

Tablo 6.

Tezlerin Çalışma Grupları Açısından Dağılımı

\begin{tabular}{|c|c|c|c|}
\hline \multirow{6}{*}{ Ortaokul } & & Doktora & Yüksek lisans \\
\hline & 8. $\sin I f$ & $2(\mathrm{D} 1, \mathrm{D} 8)$ & $4(\mathrm{Y} 11, \mathrm{Y} 15, \mathrm{Y} 20)$ \\
\hline & 7. sınıf & $2(\mathrm{D} 3, \mathrm{D} 6)$ & $3(Y 4, Y 13, Y 29, Y 31)$ \\
\hline & 6. sınif & 2 (D4, D5) & $\begin{array}{c}9(\mathrm{Y} 1, \mathrm{Y} 2, \mathrm{Y} 7, \mathrm{Y} 8, \mathrm{Y} 9, \mathrm{Y} 10, \mathrm{Y} 21, \\
\mathrm{Y} 25, \mathrm{Y30})\end{array}$ \\
\hline & 5. sinıf & 1 (D7) & 3 (Y3, Y24, Y19) \\
\hline & 5-6-7-8. sinıf & - & $1(\mathrm{Y} 16)$ \\
\hline \multirow{4}{*}{ Lise } & Sınıf belirtilmemiş & - & $1(\mathrm{Y5})$ \\
\hline & 10. sinıf & - & $1(\mathrm{Y} 17)$ \\
\hline & Sınıf belirtilmemiş & - & 1 (Y18) \\
\hline & Türkçe eğitimi (3. sınıf) & 1 (D2) & - \\
\hline \multirow{4}{*}{ Öğretmen adayı } & Türkçe eğitimi (2. sınıf) & 1 (D10) & - \\
\hline & $\begin{array}{l}\text { Türkçe eğitimi (sınıf } \\
\text { belirtilmemiş) }\end{array}$ & - & $1(\mathrm{Y} 26)$ \\
\hline & Türk dili ve edebiyatı & 1 (D9) & - \\
\hline & $\begin{array}{l}\text { Eğitim fakültesi } \\
\text { öğrencileri }\end{array}$ & - & $1(\mathrm{Y} 12)$ \\
\hline \multirow{2}{*}{ Türkçe öğretmeni } & Ortaokul öğrencileri ile & - & $1(\mathrm{Y} 22)$ \\
\hline & Türkçe öğretmenleri & - & $2(Y 23, Y 27)$ \\
\hline
\end{tabular}




\begin{tabular}{cccc}
\hline Sözlük maddesi & Ön ad & - & $1(\mathrm{Y} 6)$ \\
Kitap (Inceleme) & Wattpad (Inceleme) & - & $1(\mathrm{Y} 28)$ \\
\hline
\end{tabular}

Çalışmada incelenen tezler çalışma grupları açısından değerlendirildiğinde tezlerin ortaokul öğrencileri üzerinde çalışıldığı görülmektedir. Doktora tezlerinin \%70'i ortaokul öğrencileri üzerinde yapılırken tezlerin \%30'unun öğretmen adayları üzerinde yapıldığı görülmektedir. Yüksek lisans tezlerinin ise $\% 71^{\prime}$ i ortaokul öğrencileri üzerinde yapılmıştır. Doktora tezlerinden farklı olarak yüksek lisans tezlerinde lise öğrencileri ve Türkçe öğretmenleri üzerinde de çalışılmıştır. Bununla birlikte yüksek lisans tezlerinde öğretmen adayları üzerinde daha az çalışımıştır.

\section{Altıncı araştırma sorusuna ilişkin bulgular}

Tablo 7.

Tezlerin Çalışma Gruplarının Büyüklüğü Açısından Dağııımı

\begin{tabular}{ccc} 
& Doktora & Yüksek lisans \\
\hline $1-50$ & $4(\% 40)(\mathrm{D} 1, \mathrm{D} 3, \mathrm{D} 6, \mathrm{D} 8)$ & $12(\% 39)(\mathrm{Y} 7, \mathrm{Y} 9, \mathrm{Y} 11, \mathrm{Y} 14, \mathrm{Y} 19$, \\
& & $\mathrm{Y} 20, \mathrm{Y} 21, \mathrm{Y} 22, \mathrm{Y} 25, \mathrm{Y} 28, \mathrm{Y} 30$, \\
$51-100$ & $5(\% 50)(\mathrm{D} 2, \mathrm{D} 4, \mathrm{D} 5, \mathrm{D} 9, \mathrm{D} 10)$ & $6(\% 19)(\mathrm{Y} 1, \mathrm{Y} 4, \mathrm{Y} 13, \mathrm{Y} 17, \mathrm{Y} 24$, \\
& & $\mathrm{Y} 29)$ \\
$101-200$ & $1(\% 10)(\mathrm{D} 7)$ & $4(\% 13)(\mathrm{Y3}, \mathrm{Y} 16, \mathrm{Y} 23, \mathrm{Y} 27)$ \\
$201-500$ & - & $3(\% 10)(\mathrm{Y} 2, \mathrm{Y} 5, \mathrm{Y} 26)$ \\
$501-1000$ & - & $2(\% 6)(\mathrm{Y} 6, \mathrm{Y} 15)$ \\
$1001-1500$ & - & $1 \% 3)(\mathrm{Y} 18)$ \\
1501 ve üstü & - & $1 \% 3)(\mathrm{Y} 12)$ \\
Belirtilmemiş & - & $2(\% 6)(\mathrm{Y} 8, \mathrm{Y} 10)$ \\
\hline
\end{tabular}

Çalışmaların örneklem büyüklükleri incelendiğinde doktora tezlerinin $\% 90$ 'ının 1-100 örneklem büyüklüğüne sahip olduğu görülmektedir. Aynı büyüklük aralığında yüksek lisans tezlerinin \%58'i bulunmaktadır. 200 örneklem büyüklüğünden daha yüksek örneklem gruplu bir doktora tezi bulunmamaktadır. Yüksek lisans tezlerinin ise örneklem grupları çok daha yüksektir. Bu durumun sebebi doktora tezlerinin daha küçük grupla daha derinlemesine araştırma hedefinin bulunması olabilir.

\section{Yedinci araştırma sorusuna ilişkin bulgular}

Tablo 8.

Tezlerin Yaklaşım ve Desen Açısından Dağılımı

\begin{tabular}{ccc}
\hline Yaklaşım & Doktora & Yüksek lisans \\
Karma & $7(\% 70)(\mathrm{D} 1, \mathrm{D} 3, \mathrm{D} 4$, & $10(\% 32)(\mathrm{Y} 4, \mathrm{Y} 5, \mathrm{Y} 8, \mathrm{Y} 9, \mathrm{Y} 14, \mathrm{Y} 19$, \\
& $\mathrm{D} 5, \mathrm{D} 6, \mathrm{D} 7, \mathrm{D} 9)$ & $\mathrm{Y} 20, \mathrm{Y} 21, \mathrm{Y} 25, \mathrm{Y} 26)$ \\
Nitel & - & $5(\% 26)(\mathrm{Y} 6, \mathrm{Y} 16, \mathrm{Y} 22, \mathrm{Y} 28, \mathrm{Y} 31)$ \\
Nicel & $3(\% 30)(\mathrm{D} 2, \mathrm{D} 8$, & $16(\% 42)(\mathrm{Y} 1, \mathrm{Y} 2, \mathrm{Y} 3, \mathrm{Y} 7, \mathrm{Y} 10, \mathrm{Y} 11$, \\
& $\mathrm{D} 10)$ & $\mathrm{Y} 12, \mathrm{Y} 13, \mathrm{Y} 15, \mathrm{Y} 17, \mathrm{Y} 18, \mathrm{Y} 23, \mathrm{Y} 24$, \\
& & $\mathrm{Y} 27, \mathrm{Y} 29, \mathrm{Y} 30)$
\end{tabular}

Desen

Eş zamanlı İç içe karma Yarı deneysel Üçgenleme/Çeşitleme

$$
\begin{gathered}
2(\% 13)(D 1, D 9) \\
2(\% 13)(D 1, D 3) \\
4(\% 26)(D 2, D 6, D 8, \\
D 10) \\
1(\% 6,5)(D 4)
\end{gathered}
$$

$1(\% 3)(\mathrm{Y} 21)$

7 (\%19) (Y1, Y10, Y11, Y13, Y20,

Y24, Y25) 


\begin{tabular}{ccc}
\hline Durum çalışması & $2(\% 13)(\mathrm{D} 4, \mathrm{D} 9)$ & $2(\% 5)(\mathrm{Y} 5, \mathrm{Y} 9)$ \\
Açıklayıcı ardışık & $1(\% 6,5)(\mathrm{D} 6)$ & $1(\% 3)(\mathrm{Y} 8)$ \\
Tasarım tabanlı araştırma & $1(\% 6,5)(\mathrm{D} 7)$ & - \\
Klasik deneysel & $2(\% 13)(\mathrm{D} 5, \mathrm{D} 7)$ & $7(\% 19)(\mathrm{Y} 3, \mathrm{Y} 4, \mathrm{Y} 9, \mathrm{Y} 14, \mathrm{Y} 17, \mathrm{Y} 29$, \\
& & $\mathrm{Y} 30)$ \\
Betimsel araştırma & - & $4(\% 11)(\mathrm{Y} 6, \mathrm{Y} 23, \mathrm{Y} 27, \mathrm{Y} 30)$ \\
2x2'lik split-plot faktöryel (karışık) & - & $1(\% 3)(\mathrm{Y} 7)$ \\
desen & - & $2(\% 5)(\mathrm{Y} 12, \mathrm{Y} 23)$ \\
Tarama & - & $1(\% 3)(\mathrm{Y} 15)$ \\
Kesitsel tarama & - & $1(\% 3)(\mathrm{Y} 18)$ \\
Betimsel tarama & - & $2(\% 5)(\mathrm{Y} 16)$ \\
Ilişkisel tarama & - & $1 \% 11)(\mathrm{Y} 5, \mathrm{Y} 19, \mathrm{Y} 20, \mathrm{Y} 25)$ \\
Açımlayıcı sıralı & - & $1(\% 3)(\mathrm{Y} 26)$ \\
Tek noktada birleştirme & - & $1(\% 3)(\mathrm{Y} 28)$ \\
Doküman incelemesi & - & $1(\% 3)(\mathrm{Y} 2)$ \\
Eylem araştırması & - & \\
Nedensel karşılaştırma & - &
\end{tabular}

Doktora çalışmalarının \%70'i karma yaklaşımla yapılan çalışmalardan meydana gelirken nitel çalışma yapılmamıştır. Yüksek lisans tezlerinde ise daha dengeli bir dağılım söz konusudur. Bu durum, doktora tezlerinin çalışılan konuya farklı açılardan yaklaşma hedefiyle ilgili olabilir. Her iki grupta da en fazla kullanılan desen yarı deneysel desen olmuştur.

\section{Sekizinci araştırma sorusuna ilişkin bulgular}

Tablo 9.

Tezlerin Veri Toplama Araçları Açısından Dağııımı

\begin{tabular}{lcc} 
& Doktora & Yüksek lisans \\
Tutum, kaygı, özyeterlik ölçekleri & $17(\% 37)(\mathrm{D} 1, \mathrm{D} 3, \mathrm{D} 4$, & $35(\% 45)(\mathrm{Y} 1, \mathrm{Y} 1, \mathrm{Y} 4, \mathrm{Y} 4, \mathrm{Y} 7, \mathrm{Y} 7, \mathrm{Y} 8$, \\
& $\mathrm{D} 4, \mathrm{D} 4, \mathrm{D} 5, \mathrm{D} 6, \mathrm{D} 6, \mathrm{D} 6$, & $\mathrm{Y} 9, \mathrm{Y} 10, \mathrm{Y} 10, \mathrm{Y} 10, \mathrm{Y} 11, \mathrm{Y} 11, \mathrm{Y} 12$, \\
$\mathrm{D} 8, \mathrm{D} 8, \mathrm{D} 9, \mathrm{D} 9, \mathrm{D} 10$, & $\mathrm{Y} 13, \mathrm{Y} 13, \mathrm{Y} 14, \mathrm{Y} 14, \mathrm{Y} 15, \mathrm{Y} 16, \mathrm{Y} 16$, \\
& $\mathrm{D} 10, \mathrm{D} 10, \mathrm{D} 10)$ & $\mathrm{Y} 18, \mathrm{Y} 19, \mathrm{Y} 19, \mathrm{Y} 20, \mathrm{Y} 20, \mathrm{Y} 21, \mathrm{Y} 23$, \\
& & $\mathrm{Y} 24, \mathrm{Y} 25, \mathrm{Y} 25, \mathrm{Y} 26, \mathrm{Y} 27, \mathrm{Y} 27, \mathrm{Y} 30)$ \\
Gözlem, görüşme formları & $10(\% 22)(\mathrm{D} 1, \mathrm{D} 3, \mathrm{D} 3$, & $11(\% 14)(\mathrm{Y} 4, \mathrm{Y} 5, \mathrm{Y} 8, \mathrm{Y} 14, \mathrm{Y} 19, \mathrm{Y} 19$, \\
& $\mathrm{D} 4, \mathrm{D} 5, \mathrm{D} 6, \mathrm{D} 7, \mathrm{D} 8, \mathrm{D} 9$, & $\mathrm{Y} 20, \mathrm{Y} 20, \mathrm{Y} 22, \mathrm{Y} 31, \mathrm{Y} 31)$ \\
Başarı testleri & $\mathrm{D} 10)$ & \\
& $6(\% 13)(\mathrm{D} 1, \mathrm{D} 5, \mathrm{D} 7, \mathrm{D} 8$, & $12(\% 16)(\mathrm{Y} 1, \mathrm{Y} 2, \mathrm{Y} 3, \mathrm{Y} 8, \mathrm{Y} 11, \mathrm{Y} 13$, \\
Kişisel bilgi formları & $\mathrm{D} 9, \mathrm{D} 10)$ & $\mathrm{Y} 17, \mathrm{Y} 20, \mathrm{Y} 24, \mathrm{Y} 25, \mathrm{Y} 29, \mathrm{Y} 30)$ \\
Değerlendirme formları & $4(\%)(\mathrm{D} 1, \mathrm{D} 5, \mathrm{D} 8, \mathrm{D} 10)$ & $4(\% 5)(\mathrm{Y} 12, \mathrm{Y} 14, \mathrm{Y} 16, \mathrm{Y} 30)$ \\
Puanlama anahtarları & $1(\% 2)(\mathrm{D} 8)$ & $2(\% 3)(\mathrm{Y} 5, \mathrm{Y} 21)$ \\
Diğer & $2(\% 4)(\mathrm{D} 3, \mathrm{D} 4)$ & - \\
& $6(\% 13)(\mathrm{D} 1, \mathrm{D} 2, \mathrm{D} 2, \mathrm{D} 2$, & $13(\% 17)(\mathrm{Y} 4, \mathrm{Y} 6, \mathrm{Y} 7, \mathrm{Y} 9, \mathrm{Y} 9, \mathrm{Y} 14$, \\
& $\mathrm{D} 4, \mathrm{D} 5)$ & $\mathrm{Y} 21, \mathrm{Y} 21, \mathrm{Y} 23, \mathrm{Y} 28, \mathrm{Y} 29, \mathrm{Y} 31, \mathrm{Y} 31)$ \\
\hline
\end{tabular}

Veri toplama araçları incelendiğinde en çok başarı testleri ile tutum, kaygı, özyeterlik ölçeklerinin kullanıldığı söylenebilir. Veri toplama araçlarının doktora ve yüksek lisans tezleri arasında dengeli olduğu söylenebilir.

\section{Tartışma ve Sonuç}

Türkçe eğitimi alanında yapılmış dijital öğrenme konulu tezleri incelemek amacıyla yapılan bu çalışmada 41 tez incelenmiş ve elde edilen veriler betimsel analiz ile çözümlenmiştir. 
Tezlerin sayıları ve yıllara göre dağılımı incelendiğinde 2017 yılından sonra dijital öğrenme tezlerinde artış olduğu görülmektedir. Bununla birlikte doktora tezlerinin bütün tezlerin 1/4'ünü meydana getirdiği ifade edilebilir. Türkçe eğitiminde dijital öğrenme eğilimlerini inceleyen çalışmalarda 2017 yılından sonra artış olduğu ve doktora tezlerinin bütün tezlerin 1/3'ünü oluşturduğu görülmektedir (Delen 2021: 54; Korucu ve Biçer 2019: 37; Şahin vd. 2020). Bu sonuçlar değerlendirildiğinde Türkçe eğitimindeki dijital öğrenme tezlerinin en çok 2017 ve sonrasında yapıldığı söylenebilir. Bu durum, son yıllarda artan teknoloji kullanımının eğitimle iç içe geçmesi ve ders içi etkinliklerin teknoloji merkezli yapılmaya başlanması ile açıklanabilir. Öğrencilerin daha çok teknolojik ürünle karşılaşması, araştırmacıları teknoloji merkezli çalışmalar yapmaya sevk etmiş olabilir.

Tezlere konuları açısından bakıldığında tezlerin bir yöntemin-uygulamanın öğrencilerin çeşitli becerilerine etkisini incelediği görülmektedir. Doktora tezlerinin tamamına yakını bu türden tezlerden meydana gelmekteyken yüksek lisans tezlerinin $\% 68^{\prime} i$ etki inceleyen tezlerden meydana gelmektedir. Bunun altındaki sınıflandırma dikkate alındığında ise öğrencilerin uygulama süresince aktif veya pasif olduğu çalışmalar göze çarpmaktadır. Bütün çalışmalara bakıldığında öğrencilerin pasif olduğu çalışmaların bütün çalışmalarda büyük bir yer aldığı görülmektedir. Bununla birlikte doktora ve yüksek lisans tezlerinde öğrencilerin pasif olduğu çalışmalara bakıldığında doktora tezlerinde bu oranın daha düşük olduğu görülmektedir. Bu durum, doktora tezlerinin yeni bir yaklaşım ortaya koyma misyonuyla açıklanabilir. Konu açısından tezler, en çok dijital hikâye ve bilgisayar destekli çalışmalara yönelmiştir. Doktora tezlerinde dijital hikâye ilk sıradayken yüksek lisans tezlerinde gerilerdedir. Yüksek lisans tezlerindeyse bilgisayar destekli eğitsel oyunlar ön plana çıkmıştır. 'Dijital' kavramı üzerine Türkçe eğitimi alanında yapılan eğilim araştırmalarında bu türden bir değerlendirmeye rastlanmamıştır.

Problem, alt problemler ve amaç açısından değerlendirme yapıldı̆̆ında her iki grupta da akademik başarı ve tutum ile yazma becerilerinin incelenmesinin hedeflendiği görülmektedir. Bu alanda yapılan farklı çalışmalarda, en çok akademik başarı ve tutumun incelendiği ifade edilmiştir (Delen 2021: 64; Talan 2019: 730). Çalışma, bu çalışmalarla paralellik göstermekle birlikte akademik başarı ve tutum ile yazma becerilerinin ön plana çıkması kolay ölçülebilir beceriler olmasından kaynaklanabilir. Ayrıca, çalışmaların hedefleri dikkate alındığında öğrencilerin ürettiği, aktif olduğu çalışmalar yerine öğrencilerin çeşitli becerilerinin ölçüldüğü çalışmalar yapılmaya çalışıldığı ifade edilebilir.

Ele alınan tezler sonuçları açısından değerlendirildiğinde her iki grupta da akademik başarı ve tutumun ilk sırada yer aldığı görülmektedir. Bunun yanı sıra yüksek lisans tezlerinde olumsuz sonuçlar elde edildiği ifade edilmiştir.

Doktora tezlerinin \%70'i ortaokul öğrencileri üzerinde yapılırken \%30'nun öğretmen adayları üzerinde yapıldığı görülmektedir. Yüksek lisans tezlerinin ise \%71'i ortaokul öğrencileri üzerinde çalışımıştır. Doktora tezlerinden farklı olarak yüksek lisans tezlerinde lise öğrencileri ve Türkçe öğretmenleri üzerinde de çalışılmıştır. Bununla birlikte yüksek lisans tezlerinde öğretmen adayları üzerinde daha az çalışılmıştır. 'Dijital' kavramı içerisinde Türkçe eğitimindeki eğilimleri inceleyen çalışmalarda çalışma grubu olarak en çok ortaokul öğrencilerinin ve öğretmen adaylarının bulunduğu söylenebilir (Altınpulluk 2021: 20; Çifci ve Ünlü 2020: 1377; Delen 2021: 66; Korucu ve Biçer 2019: 39; Şahin vd. 2020: 109; Talan 2019: 698; Turgut ve Kışla 2015: 106). Bu durum, araştırmacıların çalıştıkları birimlerde araştırma yapmanın kolay olmasından ve hedef kitlenin ortaokul öğrencileri olmasından kaynaklanabilir. Bu çalışmanın bulguları, alanda yazılanlarla desteklenmektedir.

Çalışmaların örneklem büyüklükleri incelendiğinde doktora tezlerinin $\% 90$ 'ının 1-100 örneklem büyüklüğüne sahip tezlerden meydana geldiği görülmektedir. Aynı büyüklük aralığında yüksek lisans tezlerinin \%58'i bulunmaktadır. 200 örneklem büyüklüğünden daha yüksek örneklem gruplu bir doktora tezi bulunmamaktadır. Yüksek lisans tezlerinin ise örneklem grupları çok daha yüksektir. Bu durumun sebebi, doktora tezlerinin daha küçük grupla daha derinlemesine araştırma hedefinin bulunması olabilir. Yapılan çalışmalar ve bu çalışma değerlendirildiğinde örneklem büyüklüğünün 1-100 arasında olduğu görülmektedir (Altınpulluk 2021: 200; Delen 2021: 66; Korucu ve Biçer 2019: 39; Şahin vd. 2020: 110). Çalışma, yapılan öbür çalışmalarla paralellik göstermektedir. 
Doktora çalışmalarının \%70'i karma yaklaşımla yapılan çalışmalardan meydana gelirken nitel çalışma yapılmamıştır. Yüksek lisans tezlerinde ise daha dengeli bir dağılım söz konusudur. Bu durum, doktora tezlerinin çalışılan konuya farklı açılardan yaklaşma hedefiyle ilgili olabilir. Her iki grupta da en fazla kullanılan desen yarı deneysel desen olmuştur. Ilgili araştırmalara bakıldığında nicel araştırmaların daha önde olduğu görülmektedir (Altınpulluk 2021: 198; Delen 2021: 65; Korucu ve Biçer 2019: 38; Şahin vd. 2020: 108; Talan 2019: 700). Bu çalışmanın bulgularına göre karma yaklaşım daha çok kullanıııken diğer çalışmalarda nicel daha fazla kullanılmıştır.

Veri toplama araçları incelendiğinde en çok başarı testleri ile tutum, kaygı, özyeterlik ölçeklerinin kullanıldığı söylenebilir. İlgili araştırmalara bakıldığında başarı testleri, tutum ölçekleri, anket ve görüşmeler öne çıkmaktadır (Altınpulluk 2021: 199; Çifci ve Ünlü 2020: 1379; Delen 2021: 67; Şahin vd. 2020: 109; Talan 2019: 701). Bu çalışma ve diğer çalışmalar değerlendirildiğinde başarı testleri, tutum ölçekleri, anket ve görüşmeler öne çıkmaktadır. Bu sonuç, çalışmanın bulgularıyla örtüşmektedir. Ayrıca veri toplama araçları ile ilgili elde edilen bu sonuç; problem, alt problem ve amaçlar açısından yapılan değerlendirmelerden elde edilen sonuçlarla da benzerlik göstermektedir.

Çalışmanın sonuçlarına genel olarak bakıldığında çalışmaların daha çok öğrencilerin pasif kaldığı çalışmalardan oluştuğu söylenebilir. Teknoloji destekli birçok çalışma görülse de bu çalışmaların birçoğunda öğrenciler pasif kalmaktadır. Noguerón-Liu ve Lammers'e göre (2020: 420) öğretmenlerin dijital alanları ve uygulamaları okuryazarlık öğretimine nasıl dâhil edebileceklerini gösteren literatüre rağmen ortaokul yazma öğretimi ile ilgili araştırmalar, teknoloji kullanımının hâlâ çok fazla öğretmen merkezli olduğunu göstermektedir. Yine aynı araştırmalar, teknoloji odaklı eğitimin küresel düzeyde değil, yerel düzeyde kaldığını ifade etmektedir.

Çalışmadan elde edilen sonuçlar doğrultusunda şu öneriler sunulabilir:

- Öğrencilerin aktif olduğu, dijital kanalları doğrudan kullanabildiği çalışmalar yapılabilir.

- Çalışmalarda kullanılan içerik öğrencilerin seviyesine uygun ve teknolojinin getirilerini içinde barındıran seviyede olabilir.

- Öğrencilerin tutum, görüş, akademik başarılarının yanı sıra dijital yeterliklerinin de geliştirilmesine yönelik çalışmalar yapılabilir.

- Bu çalışmanın benzeri bir çalışma, yabancılara Türkçe öğretimi alanı üzerinde de yapılabilir.

\section{Araştırma ve Yayın Etiği}

Bu çalışmada "Yükseköğretim Kurumları Bilimsel Araştırma ve Yayın Etiği Yönergesi" kapsamında uyulması belirtilen tüm kurallara uyulmuştur. Yönergenin ikinci bölümü olan "Bilimsel Araştırma ve Yayın Etiğine Aykırı Eylemler" başlığı altında belirtilen eylemlerden hiçbiri gerçekleştirilmemiştir.

\section{Yazarların Katkı Oranı}

Makale, tek yazar tarafından hazırlanmıştır.

\section{Çıkar Çatışması}

Çıkar çatışması teşkil edebilecek herhangi bir durum bulunmamaktadır.

\section{Kaynaklar}

Akçay, A. (2015). Yapılandırmacı yaklaşıma dayalı ağ (web) destekli eğitimin Türkçe öğretmeni yetiştirilmesine etkisi (Doktora tezi). Erişim adresi: https://tez.yok.gov.tr/UlusalTezMerkezi/

Akçay, A. (2009). Webquest (web macerası) yönteminin Türkçe dersindeki akademik başarı ve tutuma etkisi (Yüksek lisans tezi). Erişim adresi: https://tez.yok.gov.tr/UlusalTezMerkezi/

Akgün, M. A. (2020). Türkçe öğretmeni adaylarının internete yönelik epistemolojik inançlarının araştırılması (Yüksek lisans tezi). Erişim adresi: https://tez.yok.gov.tr/UlusalTezMerkezi/

Aktaş, E. ve Uzuner Yurt, S. (2015). Türkçe eğitimi alanındaki makale özetlerine yönelik bir içerik analizi. Turkish Studies, 10(7), 73-96. 
Altınpulluk, H. (2021). Video oyunların eğitim araştırmalarında kullanımı: Bir sistematik tarama. Anadolu Üniversitesi Sosyal Bilimler Dergisi, 21(1), 185-212.

Altunbay, M. ve Bıçak, N. (2018). Türkçe eğitimi derslerinde "z kuşağı" bireylerine uygun teknoloji tabanlı uygulamaların kullanımı. ZfWT, 10(1), 127-142.

Arı, G., Yaşar, M. S. ve İstanbullu, E. (2020). Türkçe öğretmeni adaylarıyla ilgili yayımlanan makalelerin incelenmesi (2014-2018). Ana Dili Eğitimi Dergisi, 8(2), 487-508.

Aşcı, A. U. (2019). Eğitsel dijital oyunların 6. Sınıf öğrencilerinin Türkçe dersi akademik başarılarına etkisi. Ulus/ararası Sosyal Araştırmalar Dergisi, 12(62), 932-941.

Aytaş, G. ve Özcan, Ş. (2019). Türkçe eğitimi konularını temel alan drama çalışmalarına yönelik bir inceleme. Ana Dili Eğitimi Dergisi, 7(1), 235-255.

Baki, Y. (2015). Dijital öykülerin altıncı sınıf öğrencilerinin yazma sürecine etkisi (Doktora tezi). Erişim adresi: https://tez.yok.gov.tr/UlusalTezMerkezi/

Baki, Y. ve Feyzioğlu, N. (2017). Dijital öykülerin 6. sınıf öğrencilerinin öykü yazma becerilerine etkisi. International Online Journal of Educational Sciences, 9(3), 686-704.

Bal M. (2018). Türkçe dersinin 21. yüzyıl becerileri açısından incelenmesi. e-Turkish Studies, 13, 49-64.

Bal M. (2018). Çok katmanlı okuryazarlık bağlamında oyunlaştırmanın Türkçe öğretim sürecine katkısı. Ana Dili Eğitimi Dergisi, 6(1), 183-201.

Bal M. (2018). Reading and writing experiences of middle school students in the digital age: wattpad sample. International Journal of Education and Literacy Studies, 6(2), 89-100.

Bal M. (2019). Use of digital games in writing education: an action research on gamification. Contemporary Educational Technology, 10(3), 246-271.

Bal M. ve Uslu E. (2018). Türkçe öğretim sürecinde dijital bölünme. Sakarya University Journal of Education, 8(1), 228-245.

Batıbay, E. F. (2019). Web 2.0 uygulamalarının Türkçe dersinde motivasyona ve başarıya etkisi: Kahoot örneği (Yüksek lisans tezi). Erişim adresi: https://tez.yok.gov.tr/UlusalTezMerkezi/

Batluralkız, Ç. (2018). Basılı ve dijital ortamlarda ortaokul öğrencilerinin okuduğunu anlama becerilerinin karşılaştırılması (Yüksek lisans tezi). Erişim adresi: https://tez.yok.gov.tr/UlusalTezMerkezi/

Benzer, A. (2017). Dijital çağda öğretim teknolojileri ile Türkçe eğitimi. Ankara: Ideaport Yayınları.

Benzer, A. (2018). Investigation of readiness levels of Turkish teacher candidates related to digital course material preparation training. 7th International Conference on "Innovations in Learning for the Future": Digital Transformation in Education içinde (s. 9-19).

Boyacı, S. ve Demirkol, S. (2018). Türkçe eğitimi alanında yapılan doktora tezlerinin incelenmesi. Ana Dili Eğitimi Dergisi, 6(2), 512-531.

Bozkurt, B. Ü. ve Uzun, N. E. (2015). Türkçenin eğitimi-öğretimine ilişkin bir alanyazını değerlendirmesi: Uluslararası bilimsel toplantılarda eğilimler/yönelimler. Dil Eğitimi ve Araştırmaları Dergisi, 1(2), 1-15.

Cayhan, C. (2017). Ortaokul öğrencilerinin wattpad uygulaması kullanımı ile okuma ve yazma özyeterlikleri arasındaki ilişkinin incelenmesi (Yüksek lisans tezi). Erişim adresi: https://tez.yok.gov.tr/UlusalTezMerkezi/

Ceran, D., Aydın, M. ve Onarcıoğlu A. S. (2018). Okuma eğitimi üzerine yapılan tezlerde eğilimler: Bir içerik analizi çalışması. Kırşehir Eğitim Fakültesi Dergisi, 19(3), 2377-2392.

Çetin, D. (2013). Bilgisayar destekli prozodi eğitiminin vurgu, ton ve duyguyu algılama ve yansıtma becerilerine etkisi (Doktora tezi). Erişim adresi: https://tez.yok.gov.tr/UlusalTezMerkezi/

Çıvğın, H. (2020). Eğitim fakültesi öğrencilerinin dijital okuma yeterliliklerinin çeşitli değiş̧enler açısından değerlendirilmesi (Yüksek lisans tezi). Erişim adresi: https://tez.yok.gov.tr/UlusalTezMerkezi/

Çifci, M. ve Ünlü, S. (2020). Türkiye'de çevrimiçi okuma üzerine yapılan çalışmaların analizi. Ana Dili Eğitimi Dergisi, 8(4), 1368-1385.

Coşkun, E., Özçakmak, H. ve Balcı, A. (2012). Türkçe eğitiminde eğilimler 1981-2010 yılları arasında yapılan tezler üzerine bir meta-analiz çalışması. Uluslararası Türkçenin Eğitimi-Öğretimi Kurultayında sunulan bildiri, 204-212. 
Dayan, G. ve Girmen, P. (2018). Türkçe eğitimi yazma sürecinde: Dijital öyküleme. Eğitimde Nitel Araştırmalar Dergisi, 6(3), 207-228.

Delen, A. (2021). Türkiye'de e-öğrenme ortamlarına ilişkin yapılan araştırmalardaki eğilimler: 20042020 dönemi tezlerin incelenmesi (Yüksek lisans tezi). Erişim adresi: https://tez.yok.gov.tr/UlusalTezMerkezi/

Demirer, V. ve Baki Y. (2018). Türkçe öğretmeni adaylarının dijital öyküleme sürecine ilişkin görüşleri ve algıları. Kuramsal Eğitimbilim Dergisi, 11(4), 718-747.

Doğan, Y. ve Özçakmak, H. (2014). Dinleme becerisinin eğitimi üzerine yapılan lisansüstü tezlerin değerlendirilmesi. Ana Dili Eğitimi Dergisi, 2(2), 90-99.

Dönmez, A. (2020). Fiil ve fiille bağlantılı konuların öğretiminde bilgisayarla desteklenmiş oyun tabanlı ögrenme uygulamalarının etkililiği (Yüksek lisans tezi). Erişim adresi: https://tez.yok.gov.tr/UlusalTezMerkezi/

Dönmez, B. ve Gündoğdu, K. (2016). 2000-2016 yılları arasında Türkçe öğretim programları alanında yayımlanan makale ve tezlerin analizi. Uluslararası Türkçe Edebiyat Kültür Eğitim Dergisi, 5(4), 2109-2125.

Duran, E. ve Ertan Özen, N. (2018). Türkçe derslerinde dijital okuryazarlık. Türkiye Eğitim Dergisi, 3(2), 31-46.

Durukan, E. (2011). ilköğretim 6. sınıfta bilgisayar destekli dilbilgisi öğretiminin başarı ve tutuma etkisi (Doktora tezi). Erişim adresi: https://tez.yok.gov.tr/UlusalTezMerkezi/

Eroğlu, A. (2020). Ortaokul 7. sınıf Türkçe dersinde dijital hikâye anlatımının kullanılması (Doktora tezi). https://tez.yok.gov.tr/UlusalTezMerkezi/

Eroğlu, A. (2020). Türkçe öğretmeni adaylarının dijital hikâyeye yönelik metaforik algıları. Rumeli Dil ve Edebiyat Araştırmaları Dergisi, (18), 49-60.

Eroğlu, A. (2015). Ortaokul 8. sını öğrencilerinin Türkçe dersinde kullanılan tablet bilgisayar ile yazı yazmaya yönelik hazırbulunuşlukları (Yüksek lisans tezi). Erişim adresi: https://tez.yok.gov.tr/UlusalTezMerkezi/

Ertan Özen, N. (2020). Dijital hikâye oluşturmanın ortaokul 7. sınıf öğrencilerinin yaratıcı düşünme becerisine katkısı (Doktora tezi). https://tez.yok.gov.tr/UlusalTezMerkezi/

Ertem, i. S. (2016). Oyun temelli dijital ortamlar ve Türkçe öğretiminde kullanımına ilişkin sınıf öğretmenlerinin görüşleri. Akdeniz Eğitim Araştırmaları Dergisi, 10(20), 1-10.

Farıdah, I. vd. (2020). Effect digital learning on student motivation during covid-19. The 8th International Conference on Cyber and IT Service Management. October 23-24.

Fırat, M. (2009). Bireyselleştirilebilir bir e-öğrenme aracı olarak dijital konu haritaları. Biliş̧im Teknolojileri Dergisi, 2(3), 27-32.

Geçgel, H. (2020). Türkçe eğitiminde dijital yetkinlik kavramının farklı değişkenler açısından incelenmesi. Ana Dili Eğitimi Dergisi, 8(3), 886-904.

Gülce Özkaya, P. (2017). Bilgi teknolojilerine dayalı hikâye anlatımıyla öbek-anlam ilişkisinin kavranması (Doktora Tezi). Erişim adresi: https://tez.yok.gov.tr/UlusalTezMerkezi/

Gündüz, N. (2019). Dijital öykü yazarlığının çeşitli değişkenlere göre incelenmesi (Yüksek lisans tezi). Erişim adresi: https://tez.yok.gov.tr/UlusalTezMerkezi/

Işıksalan, S. N. (2020). Türkçe öğretmen adaylarının dijital ortamlardan yararlanma durumlarına ilişkin görüşlerinin incelenmesi. Turkish Studies-Applied Sciences, 15(3), 401-415.

Kahraman, E. (2013). Türkçe öğretmenlerinin bilgisayar destekli eğitime ve teknolojiye yönelik tutumları arasındaki ilişkinin incelenmesi (Yüksek lisans tezi). Erişim adresi: https://tez.yok.gov.tr/UlusalTezMerkezi/

Karacaoğlu, H. (2018). Dijital hikayelerin Türkçe dersi değerler eğitimine yönelik etkisinin incelenmesi (Yüksek lisans tezi). Erişim adresi: https://tez.yok.gov.tr/UlusalTezMerkezi/

Karadağ, K. (2019). Öğretim teknolojilerinden storybird uygulamasının 5. sınıf öğrencilerinin yaratıcı yazma becerilerine ve yazmaya yönelik tutumlarına etkisi (Yüksek lisans tezi). Erişim adresi: https://tez.yok.gov.tr/UlusalTezMerkezi/ 
Karadüz, A. ve Baytak, A. (2010). Teknoloji destekli öğretimin Türkçe eğitimi bölümü öğrencileri tarafından nasıl algılandığının incelenmesi. Sakarya Üniversitesi Eğitim Fakültesi Dergisi, $0(20), 7-29$.

Karagöz, B. ve Şeref, i. (2020) Yazma becerisiyle ilgili makaleler üzerine bir inceleme: Web Of Science veri tabanında eğilimler. Ana Dili Eğitimi Dergisi, 8(1), 67-86.

Karakuş Tayşi, E. (2019). Bilgisayar destekli materyal kullanımının öğrencilerin Türkçe dersine yönelik tutumlarına etkisi. Ana Dili Eğitimi Dergisi, 7(1), 256-272.

Karaosmanoğlu, P. (2019). Wattpad kitapları üzerine bir içerik çözümlemesi (Yüksek lisans tezi). Erişim adresi: https://tez.yok.gov.tr/UlusalTezMerkezi/

Kavan, N. (2020). Teknoloji destekli eğitimin özel eğitim öğrencilerinin okuduğunu anlama becerilerine etkisi (Yüksek lisans tezi). Erişim adresi: https://tez.yok.gov.tr/UlusalTezMerkezi/

Kaya, M. (2019). Ortaöğretim öğrencilerinin e-yazma alıskanlıklarının değerlendirilmesi (Yüksek lisans tezi). Erişim adresi: https://tez.yok.gov.tr/UlusalTezMerkezi/

Kayan, A. (2019). Ad ve adla bağlantılı konuların öğretiminde bilgisayar destekli eğitsel oyunların etkisi (Yüksek lisans tezi). Erişim adresi: https://tez.yok.gov.tr/UlusalTezMerkezi/

Kemiksiz, Ö. (2017). Dinleme becerisi üzerine yazılan makalelerin değerlendirilmesi. International Journal of Languages' Education and Teaching, 5(1), 511-531.

Kırboğa, A. (2019). Bilgisayar destekli noktalama işaretleri materyallerinin ortaokul 5. sınıf öğrencilerinin noktalama işaretleri kazanımlarına etkisi (Yüksek lisans tezi). Erişim adresi: https://tez.yok.gov.tr/UlusalTezMerkezi/

Korucu, A. T. ve Biçer, H. (2018). Mobil öğrenme: 2010-2017 çalışmalarına yönelik bir içerik analizi. Trakya Eğitim Dergisi, 9(1), 32-43.

Kurudayıoğlu M. ve Bal M. (2014). Ana dili eğitiminde dijital hikâye anlatımlarının kullanımı. Sakarya Üniversitesi Eğitim Fakültesi Dergisi, 28, 74-95.

Kurudayıoğlu, M. ve Soysal, T. (2020). 2018 Türkçe dersi öğretim programı́nın dijital yetkinlik bakımından incelenmesi. Mehmet Akif Ersoy University Journal of Education Faculty, 54, 184199.

Luong, J. ve Arnold, R. (2020). Creating a digital learning community: Four key considerations for remote learning during a pandemic. An International Conference on Engineering, Technology and Education, 8(11), 1109-1118.

Maden, A. (2019). Ortaokul öğrencilerine yönelik elektronik görsel sözlük geliştirme tasarım tabanlı bir araştırma (5. sınıf örneği) (Doktora tezi). Erişim adresi: https://tez.yok.gov.tr/UlusalTezMerkezi/

Martínez-Bravo, M.-C., Sádaba-Chalezquer, C. ve Serrano-Puche, J. (2020). Fifty years of digital literacy studies: A meta-research for interdisciplinary and conceptual convergence. Profesional de la información, 29(4).

MEB (2019). Türkçe öğretim programı. Ankara.

Mete, G. (2021). Turkish teachers' views on educational digital games. International Online Journal of Educational Sciences, 13(2), 604-619.

Noguerón-Liu, S. ve Lammers, J. C. (2020). Literacy instruction and digital Innovation: Trends and affordances for digital equity in classrooms. E. B. Moje; P. Afflerbach; P. Enciso; N. K. Lesaux (Ed), Handbook of Reading Research Volume V içinde. (s. 406-423). New York: Routledge.

Ovalı, T. (2011). Illköğretim sekizinci sınıf Türkçe dersinde bilgisayar destekli öğretimin öğrencilerin anlama becerisine etkisi (Yüksek lisans tezi). Erişim adresi: https://tez.yok.gov.tr/UlusalTezMerkezi/

Önal, A. (2020). Çevrim içi iş birlikli öğrenme yönteminin ortaokul öğrencilerinin ikna edici yazma becerilerine ve yazma kaygılarına etkisi (Yüksek lisans tezi). Erişim adresi: https://tez.yok.gov.tr/UlusalTezMerkezi/

Öz, G. (2020). 1923-1928 yılları arasında yayımlanan dergilerde Türkçe eğitimi ile ilgili makalelerin incelenmesi (Doktora tezi). Erişim adresi: https://tez.yok.gov.tr/UlusalTezMerkezi/

Özbal, A. (2017). Yazma becerisinin geliştirilmesinde web 2.0 araçlarının kullanılması (Yüksek lisans tezi). Erişim adresi: https://tez.yok.gov.tr/UlusalTezMerkezi/ 
Özbay, M. ve Özdemir, O. (2014). Türkçe öğretim programı için bir öneri: Dijital okuryazarlığa yönelik amaç ve kazanımlar. Okuma Yazma Eğitimi Araştırmaları, 2(2), 31-40.

Özçakmak, H. (2017). Türkçe eğitimi lisansüstü araştırmalarında yeni yönelimler (2011-2015). Uluslararası Türkçe Edebiyat Kültür Eğitim Dergisi, 6(3), 1607-1618.

Özdemir, O. (2017). Türkçe öğretiminde dijital teknolojilerin kullanımı ve bir web uygulaması örneği. e-Turkish Studies, 12(4), 427-444.

Özdemir, S. (2018). Okumaya ilişkin lisansüstü araştırmaların eğilimleri. Ana Dili Eğitimi Dergisi, 6(4), 1161-1178.

Özel, N. (2016). Bilgi ve iletişim teknolojilerinin etkisiyle değişen bilgi kaynakları, hizmetleri ve öğrenme ortamları. Millî Eğitim, 45(209), 270-294.

Özerbaş, M. A. ve Öztürk, Y. (2017). Türkçe dersinde dijital hikâye kullanımının akademik başarı, motivasyon ve kalıcılık üzerinde etkisi. TÜBAV Bilim Dergisi, 10(2), 102-110.

Özipek, K. (2019). Padlet uygulamasının öğrencilerin akademik başarıları ile teknolojiye ve Türkçe dersine karşı tutumlarına etkisi (Yüksek lisans tezi). Erişim adresi: https://tez.yok.gov.tr/UlusalTezMerkezi/

Özkaya, P. G. (2020). Dijital öykülerin Türkçe dil becerilerinin gelişimine etkisi: Bir meta analiz çalışması. Ana Dili Eğitimi Dergisi, 8(4), 1386-1405.

Özkoyuncu, Y. (2016). Ortaöğretim 10. sınıf öğrencilerinin fiil ve fiilimsler konusunu öğrenmede bilgisayar destekli ögrretim yönteminin öğrenci başarısı ve kalıcılığına etkisi (Yüksek lisans tezi). Erişim adresi: https://tez.yok.gov.tr/UlusalTezMerkezi/

Sevim, O. (2013). Sekizinci sınıf Türkçe dersi kişisel gelişim temasının öğretiiminde etkileşimli bilgisayar uygulamalarını etkileri (Doktora tezi). Erişim adresi: https://tez.yok.gov.tr/UlusalTezMerkezi/

Soylu, S. (2020). Deyim öğretiminde kavram karikatürü kullanımının öğrencilerin akademik başvuru ve tutumlarına etkisi (Toondoo uygulaması örneği) (Yüksek lisans tezi). Erişim adresi: https://tez.yok.gov.tr/UlusalTezMerkezi/

Şahin, A., Çiftçi, B. ve Başbayrak, M. (2020). Teknoloji destekli Türkçe eğitimi tezlerinin eğilimleri. Uluslararası Eğitim Bilim ve Teknoloji Dergisi, 6(2), 98-114.

Şanal, A. (2016). Ders kitabı olarak z-kitap kullanımının okuduğunu anlamaya etkisi (Yüksek lisans tezi). Erişim adresi: https://tez.yok.gov.tr/UlusalTezMerkezi/

Şener, F. (2019). Teknopedagojik eğitim kapsamında Türkçe öğretmenlerinin web 2.0 araçlarını kullanma durumları (Yüksek lisans tezi). Erişim adresi: https://tez.yok.gov.tr/UlusalTezMerkezi/

Şimşek, B. (2018). Çevrim içi oyunların Türkçenin söz varlığına etkisinin incelenmesi (Yüksek lisans tezi). Erişim adresi: https://tez.yok.gov.tr/UlusalTezMerkezi/

Talan, T. (2019). Dijital öyküleme yöntemi ile ilgili yapılan çalışmalara sistematik bir bakış. 7. Uluslararası Öğretim Teknolojileri ve Öğretmen Eğitimi Sempozyumu Tam Metin Kitabı, 692709.

Tayfa, H. (2018). Etkileşimli tahtanın Türkçe dersinde kullanımının ortaokul öğrencilerinin akademik başarı ve tutumlarına etkisi (Yüksek lisans tezi). Erişim adresi: https://tez.yok.gov.tr/UlusalTezMerkezi/

Tok, M. ve Potur, Ö. (2015). Yazma eğitimi alanında yapılan akademik çalışmaların eğilimleri (20102014 Yılları). Ana Dili Eğitimi Dergisi, 3(4), 1-25.

Trilling, B. ve Fadel, C. (2009). 21st century skills. Jossey-Bass A Wiley Imprint, 6(8), 1213-1228.

Turgut, G. ve Kışla, T. (2015). Bilgisayar destekli hikâye anlatımı yöntemi: Alanyazın araştırması. Turkish Online Journal of Qualitative Inquiry, 6(2). 97-121.

Tüfekçioğlu, B. (2013). Derlem tabanlı çevrim içi Türkçe öğrenci sözlüğü -Önadlar a madde başı(Yüksek lisans tezi). Erişim adresi: https://tez.yok.gov.tr/UlusalTezMerkezi/

Türker, F. M. (2014). Web tabanlı uzaktan Türkçe öğretimi uygulamalarının yazılı anlatım dersinde başarı ve tutuma etkisi (Doktora tezi). Erişim adresi: https://tez.yok.gov.tr/UlusalTezMerkezi/ 
Urfalı Dadandı, P. (2016). Türkçe öğretiminde elektronik ders kitabı kullanmanın başarı, özyeterlik inançları ve tutuma etkisi (Yüksek lisans tezi). Erişim adresi: https://tez.yok.gov.tr/UlusalTezMerkezi/

Varışoğlu, B., Şahin, A. ve Göktaş, Y. (2013). Türkçe eğitimi araştırmalarında eğilimler. Kuram ve Uygulamada Eğitim Bilimleri, 13(3). 1767-1781.

Yanbıyık, S. ve Yılmaz, F. (2016). Literatür temelli bir araştırma: Türkçe öğretiminin sorunları. Journal of Research in Educatıon and Society, 3(1). 60-75.

Yıldırım, A. ve Şimşek, H. (2018). Sosyal bilimlerde nitel araştırma yöntemleri. Ankara: Seçkin Yayıncilık.

Yılmaz, Y., Üstündağ, M. T., Güneş, E. ve Çalışkan, G. (2017). Dijital hikayeleme yöntemi ile etkili Türkçe öğretimi. Eğitim Teknolojisi Kuram ve Uygulama, 7(2), 254-275.

Yüksel, H. (2019). Türkçe dersinde kullanılan eğitsel dijital oyunların ders başarısı ve motivasyona etkisi (Yüksek lisans tezi). Erişim adresi: https://tez.yok.gov.tr/UlusalTezMerkezi/

Yürektürk, F. N. (2019). Teknolojiye dayalı yürütülen Türkçe derslerinin öğretmen ve öğrenci görüşleri bağlamında değerlendirilmesi (Yüksek lisans tezi). Erişim adresi: https://tez.yok.gov.tr/UlusalTezMerkezi/

https://www.nisanyansozluk.com/?k=dijital (9.5.2021 tarihinde erişildi.)

https://www.merriam-webster.com/dictionary/digit (9.5.2021 tarihinde erişildi.)

http://lugatim.com/s/D\%C4\%BOJ\%C4\%BOTAL (9.5.2021 tarihinde erişildi.)

\section{Introduction}

\section{Extended Abstract}

Technology is the basis of the changes that have occurred in many aspects of life in the 21st century. The concept digital has entered our lives as a result of technological changes. This concept appears in different forms in people's lives and brings with it some responsibilities. Foremost of those are digital competencies which are also important in Turkish education.

As in many fields, studies on digital learning are carried out in Turkish education. This study aimed to investigate the theses on digital learning in the field of Turkish education to help guide researchers interested in the field by establishing the status quo.

When the relationship between digital technologies and reading and writing skills is considered, it is seen that there is a two-way relationship. The first of these refers to the ability of individuals to correctly interpret the instructions, commands, signs, and visuals they encounter in digital environments and use digital tools effectively. The other includes the ability of individuals to share the written and visual materials they have created regularly and functionally (Özbay and Özdemir 2014: 32).

With the spread of computer and internet technologies, the idea of learning in the electronic medium has attracted great attention worldwide. It is possible to classify the e-learning efforts on the basis of three major phases from the emergence of computers in the 1960s to the present day. The tendency to learn in the electronic environment began with educational software that provided practice in basic skills and has gained great momentum, especially with the instant communication opportunities provided via the internet, which reached the World Wide Web in 1991. Thus, computer-based educational software was replaced by server-based learning management systems (LMS). Therefore, content creation and control have also increased from CD-ROM to Web-based software languages (FIrat 2009: 28).

Being informed of the trends in the field of digital learning will guide researchers interested in digital studies in Turkish education. In this study, the aim was to identify the general trends in theses on digital learning in teaching Turkish. From this point of view, this study was shaped around the question: "What are the trends in theses on digital learning in the field of Turkish education?"

\section{Method}

This study is qualitative by nature and was designed as a case study. According to Yıldırım and Şimşek (2018: 289), a case study is a research method that allows the researcher to examine in- 
depth a phenomenon or event that $\mathrm{s} /$ he cannot control. Case study design was used because the characteristics and tendencies of the theses investigated in this study were directly examined as well.

Document analysis was used to collect data. Document review was used for data analysis as "it is the analysis of written materials containing information about the case or cases that are targeted to be investigated" (Yıldırım and Şimşek 2018: 189).

A Thesis Review Form was used in the data collection process. The form was prepared in line with the works of the researchers in the field and the research questions of the study. First, the units to be included in the form were determined in line with the purpose of the study and the research questions. The drafted form was sent to two field experts and the final version of the form was thus prepared. The form consisted of Thesis Name, Type, Year, Subject, Research Problem, Sub-problems of the Research, Purpose of the Research, Study Group, Method-Pattern Used, Data Collection, and Conclusion sections to investigate the theses.

A Thesis Classification Form was created to classify the raw data. This form was used to determine the relevance of the theses obtained during the initial search. Through this form, the theses relevant to the purpose of the study were selected.

To collect data, theses on digital learning in the field of Turkish education in the Higher Education Council National Thesis Center were surveyed between 19.3.2021 and 8.4.2021. Theses added after those dates were excluded from the study. A total of 41 studies, 10 of which were doctoral dissertations and 31 were Master's theses, comprised the data of this study.

\section{Results and Discussion}

In terms of the year of completion, it was found that there has been an increase in the number of theses on digital learning since 2017. Doctoral theses constitute one-quarter of all of the theses.

When the theses were classified in terms of their scopes, it was observed that they investigated the administration of methods on teaching various skills and their effects on learners. Almost all doctoral theses focused on skill teaching, and $68 \%$ of the master's theses investigated the impacts of teaching. The students in those studies appear passive participants in the process.

$70 \%$ of the doctoral theses were conducted with secondary school students and $30 \%$ were on teacher candidates. $71 \%$ of the master's theses included secondary school students as participants. Unlike the doctoral theses, high school students and Turkish teachers were included in master's theses as well.

When the sample sizes of the studies were examined, it was observed that $90 \%$ of the doctoral theses and 58\% of the master's theses consisted of sample sizes ranging from 1-100.

$70 \%$ of doctoral studies consisted of studies conducted with a mixed approach. No qualitative studies were conducted. There was a more balanced distribution in the master's theses. This may have been related to the aim of the doctoral theses to approach the studied subject from different angles.

When the data collection tools were examined, it was seen that achievement tests and attitude, anxiety, and self-efficacy scales were mostly used.

\section{Ekler}

Ek-1. Çalışmada İncelenen Yüksek Lisans ve Doktora Tezleri

Tablo 10.

Çalışmada Incelenen Yüksek Lisans ve Doktora Tezleri

\begin{tabular}{llc} 
& Ad ve adla bağlantılı konuların öğretiminde bilgisayar destekli eğitsel oyunların etkisi & Y1 \\
\cline { 2 - 3 } Yüksek & $\begin{array}{l}\text { Basılı ve dijital ortamlarda ortaokul öğrencilerinin okuduğunu anlama becerilerinin } \\
\text { lisans }\end{array}$ & Y2 \\
\cline { 2 - 3 } tezleri & $\begin{array}{l}\text { Bilgisaşayar destekli noktalama işaretleri materyallerinin ortaokul 5. sınıf } \\
\text { öğrencilerinin noktalama işaretleri kazanımlarına etkisi }\end{array}$ & Y3 \\
\cline { 2 - 3 } & Çevrim içi iş birlikli öğrenme yönteminin ortaokul öğrencilerinin ikna edici yazma & Y4 \\
\hline
\end{tabular}


becerilerine ve yazma kaygılarına etkisi

Çevrim içi oyunların türkçenin söz varlığına etkisinin incelenmesi

Derlem tabanlı çevrim içi Türkçe öğrenci sözlüğü -Önadlar a madde başı- $\quad$ Y6

$\begin{array}{ll}\text { Ders kitabı olarak z-kitap kullanımının okuduğunu anlamaya etkisi } & \text { Y7 }\end{array}$

Deyim öğretiminde kavram karikatürü kullanımının öğrencilerin akademik başvuru $\quad$ Y8

ve tutumlarına etkisi (Toondoo uygulaması örneği)

Dijital hikayelerin Türkçe dersi değerler eğitimine yönelik etkisinin incelenmesi $\quad$ Y9

\begin{tabular}{ll}
\hline Dijital öykü yazarlığının çeşitli değişkenlere göre incelenmesi & Y10
\end{tabular}

Etkileşimli tahtanın Türkçe dersinde kullanımının ortaokul öğrencilerinin akademik $\quad$ Y11

başarı ve tutumlarına etkisi

Eğitim fakültesi öğrencilerinin dijital okuma yeterliliklerinin çeşitli değişkenler $\quad$ Y12

açısından değerlendirilmesi

Fiil ve fiille bağlantılı konuların öğretiminde bilgisayarla desteklenmiş oyun tabanlı $\quad$ Y13

öğrenme uygulamalarının etkililiği

İlköğretim sekizinci sınıf Türkçe dersinde bilgisayar destekli öğretimin öğrencilerin $\quad$ Y14

anlama becerisine etkisi

Ortaokul 8. sınıf öğrencilerinin Türkçe dersinde kullanılan tablet bilgisayar ile yazı $\quad$ Y15

yazmaya yönelik hazırbulunuşlukları

Ortaokul öğrencilerinin wattpad uygulaması kullanımı ile okuma ve yazma $\quad$ Y16

özyeterlikleri arasındaki ilişkinin incelenmesi

Ortaöğretim 10. sınıf öğrencilerinin fiil ve fiilimsler konusunu öğrenmede bilgisayar $\quad$ Y17

destekli öğretim yönteminin öğrenci başarısı ve kalııılığına etkisi

Ortaöğretim öğrencilerinin e-yazma alışkanlıklarının değerlendirilmesi $\quad$ Y18

Öğretim teknolojilerinden storybird uygulamasının 5. sınıf öğrencilerinin yaratıcı $\quad$ Y19

yazma becerilerine ve yazmaya yönelik tutumlarına etkisi

Padlet uygulamasının öğrencilerin akademik başarıları ile teknolojiye ve Türkçe $\quad$ Y20

dersine karşı tutumlarına etkisi

Teknoloji destekli eğitimin özel eğitim öğrencilerinin okuduğunu anlama becerilerine $\quad$ Y21

etkisi

Teknolojiye dayalı yürütülen Türkçe derslerinin öğretmen ve öğrenci görüşleri

bağlamında değerlendirilmesi

Teknopedagojik eğitim kapsamında Türkçe öğretmenlerinin web 2.0 araçlarını

kullanma durumları

Türkçe dersinde kullanılan eğitsel dijital oyunların ders başarısı ve motivasyona etkisi $\quad$ Y24

Türkçe öğretiminde elektronik ders kitabı kullanmanın başarı, özyeterlik inançları ve $\quad$ Y25 tutuma etkisi

Türkçe öğretmeni adaylarının internete yönelik epistemolojik inançlarının

araştırılması

Türkçe öğretmenlerinin bilgisayar destekli eğitime ve teknolojiye yönelik tutumları

arasındaki ilişkinin incelenmesi

Wattpad kitapları üzerine bir içerik çözümlemesi

Web 2.0 uygulamalarının Türkçe dersinde motivasyona ve başarıya etkisi kahoot $\quad$ Y29 örneği

Webquest (web macerası) yönteminin Türkçe dersindeki akademik başarı ve tutuma $\quad$ Y30 etkisi

Yazma becerisinin geliştirilmesinde web 2.0 araçlarının kullanılması $\quad$ Y31

Bilgi teknolojilerine dayalı hikâye anlatımıyla öbek-anlam ilişkisinin kavranması $\quad$ D1

Doktora $\quad$ Bilgisayar destekli prozodi eğitiminin vurgu, ton ve duyguyu algılama ve yansıtma $\quad$ D2

tezleri becerilerine etkisi

Dijital hikâye oluşturmanın ortaokul 7. sınıf öğrencilerinin yaratıcı düşünme 
becerisine katkısı

Dijital öykülerin altıncı sınıf öğrencilerinin yazma sürecine etkisi D4

ilköğretim 6. sınıfta bilgisayar destekli dilbilgisi öğretiminin başarı ve tutuma etkisi

D5

Ortaokul 7. sınıf Türkçe dersinde dijital hikâye anlatımının kullanılması

Ortaokul öğrencilerine yönelik elektronik görsel sözlük geliştirme tasarım tabanlı bir

D7
araştırma (5. sınıf örneği)

Sekizinci sınıf Türkçe dersi kişisel gelişim temasının öğretiminde etkileşimli bilgisayar D8 uygulamalarının etkileri

Web tabanlı uzaktan Türkçe öğretimi uygulamalarının yazılı anlatım dersinde başarı ve tutuma etkisi

Yapılandırmacı yaklaşıma dayalı ağ (web) destekli eğitimin Türkçe öğretmeni yetiştirilmesine etkisi 